OPEN ACCESS

Edited by:

Changiz Geula,

Northwestern University,

United States

Reviewed by:

Darius John Rowland Lane,

University of Sydney, Australia Andrew C. Gill,

University of Lincoln, United Kingdom

*Correspondence:

Ali A. Saboury

saboury@ut.ac.ir

Received: 02 August 2017

Accepted: 28 December 2017

Published: 23 January 2018

Citation:

Bagheri S, Squitti R, Haertlé T,

Siotto M and Saboury AA (2018)

Role of Copper in the Onset of Alzheimer's Disease Compared to

Other Metals.

Front. Aging Neurosci. 9:446.

doi: 10.3389/fnagi.2017.00446

\section{Role of Copper in the Onset of Alzheimer's Disease Compared to Other Metals}

\author{
Soghra Bagheri ${ }^{1}$, Rosanna Squitti ${ }^{2}$, Thomas Haertlé ${ }^{3,4,5}$, Mariacristina Siotto $^{6}$ and \\ Ali A. Saboury ${ }^{3 *}$ \\ ${ }^{1}$ Medical Biology Research Center, Kermanshah University of Medical Sciences, Kermanshah, Iran, ${ }^{2}$ Molecular Markers \\ Laboratory, IRCCS Istituto Centro San Giovanni di Dio-Fatebenefratelli, Brescia, Italy, ${ }^{3}$ Institute of Biochemistry and \\ Biophysics, University of Tehran, Tehran, Iran, ${ }^{4}$ UR 1268 Biopolymères Interactions Assemblages, Institut National de la \\ Recherche Agronomique, Equipe Fonctions et Interactions des Protéines, Nantes, France, ${ }^{5}$ Department of Animal Nutrition \\ and Feed Management, Poznan University of Life Sciences, Poznań, Poland, ${ }^{6}$ Fondazione Don Carlo Gnocchi Onlus, Milan, \\ Italy
}

Alzheimer's disease (AD) is a neurodegenerative disorder that is characterized by amyloid plaques in patients' brain tissue. The plaques are mainly made of $\beta$-amyloid peptides and trace elements including $\mathrm{Zn}^{2+}, \mathrm{Cu}^{2+}$, and $\mathrm{Fe}^{2+}$. Some studies have shown that $\mathrm{AD}$ can be considered a type of metal dyshomeostasis. Among metal ions involved in plaques, numerous studies have focused on copper ions, which seem to be one of the main cationic elements in plaque formation. The involvement of copper in $A D$ is controversial, as some studies show a copper deficiency in $A D$, and consequently a need to enhance copper levels, while other data point to copper overload and therefore a need to reduce copper levels. In this paper, the role of copper ions in AD and some contradictory reports are reviewed and discussed.

Keywords: Alzheimer's disease, copper, zinc, neurodegenerative disorder, amyloid plaques, cholesterol, calcium

\section{INTRODUCTION}

Alzheimer's disease (AD) is a progressive neurodegenerative disorder described in 1907 by Alois Alzheimer. He observed amyloid plaques and neurofibrillary tangles (NFTs) in the brain of patients showing signs of dementia (Sarell, 2010). Today, AD is the most prevalent neurodegenerative disease affecting $10 \%$ of people aged $65+$ and $50 \%$ of people aged $80+$ (Zhang et al., 2011). In 2016, it was estimated that there were about 47 million $\mathrm{AD}$ patients in the world and this number is expected to increase to more than 130 million by 2050. The World Alzheimer Report evaluated the annual social and economic cost of dementia to be US\$ 818 billion worldwide in 2015 and this amount is expected to increase to one trillion by 2018 (Unzeta et al., 2016).

Alzheimer's disease is ultimately lethal, characterized by the developing damage of neuronal tissues in the brain. Signs include memory loss, paranoia, loss of reasoning powers and confusion (Sarell, 2010). Unfortunately, AD is recognized only after the manifestation of cognitive signs, which may be too late for effective treatment (Leskovjan et al., 2011). Moreover, approved drugs have inconsiderable effects on patients' well-being, which may be because many factors are responsible for AD (Conte-Daban et al., 2016; Pickart et al., 2017). Indeed, there are several theories to demonstrate the cause of $\mathrm{AD}$ supported by empirical data, which have been reviewed by Armstrong (2013). 
In brain regions affected in $\mathrm{AD}$, such as the cortex and hippocampus, extracellular senile plaques, and intracellular NFTs accumulate (Zhang et al., 2011). Senile plaques or amyloid plaques, as the name implies, are mainly composed of small peptides called $\beta$-amyloid (Masters et al., 1985). The latter is produced from $\beta$-amyloid precursor protein (APP) through successive cleavages first by $\beta$-secretase at residue 671 and then by $\gamma$-secretase at residues 711 or 713 (residue numbering according to the $\mathrm{APP}_{770}$ isoform) in amyloidogenic pathway. Alternatively, APP molecules can be cleaved by $\alpha$-secretase within the $\beta$-amyloid domain at residue 687 and prevent $\beta$-amyloid production in non-amyloidogenic pathway (Selkoe, 2001; Zhang et al., 2011). There are three main isoforms of APP including APP695, APP751, and APP770 with APP695 being expressed at high levels in brain compared to other isoforms (Nalivaeva and Turner, 2013). Furthermore, NFTs, mainly composed of tau proteins, is the other important factor that accumulate in AD brain (Buée et al., 2000). Tau proteins mostly expressed in neurons have the ability to induce microtubule assembly in vitro (Weingarten et al., 1975; Cleveland et al., 1977). In fact, microtubules, one of the main components of the cytoskeletal system, are involved in the maintenance of neuronal morphology and the formation of axonal and dendritic processes (Gendron and Petrucelli, 2009). One of the first and most severely injured brain areas in $\mathrm{AD}$ is the hippocampus, which is associated with neurogenesis and long-term memory storage. It is also thought to be more susceptible to metal disturbance than other brain areas. Another brain region that suffers from damage in $\mathrm{AD}$ due to plaque pathology is the cortex, associated with functions such as argumentation, feeling, and language (Leskovjan et al., 2011).

$\beta$-amyloid aggregations into senile plaques are one of the main characteristics of AD (Wan et al., 2011). A considerable co-localization of adenosine receptors and $\beta$-amyloid has been reported in senile plaques (Angulo et al., 2003). Adenosine, a purine ribonucleoside that has neuromodulatory and neuroprotective properties (Rahman, 2009), affects various important brain functions such as sleep, cognition, memory, and neurodegeneration (De Mendonça and Ribeiro, 1996; Porkka-Heiskanen, 1999; Ribeiro et al., 2002; Rahman, 2009). Adenosine is involved in numerous neurological disorders including AD (Cortés et al., 2015; Maiuolo et al., 2016). It exerts its various effects via its receptors, and thus managing its receptor agonists and antagonists significantly influences learning and memory (Ohno and Watanabe, 1996; Kopf et al., 1999; Corodimas and Tomita, 2001; Hauber and Bareiß, 2001; Pereira et al., 2002). On one hand, deamination of adenosine to inosine by adenosine deaminase (ADA) is one of the metabolic pathways for the catabolism of adenosine in the brain (Boison, 2006). On the other hand, ADA acts as an allosteric modulator of adenosine receptors (Cortés et al., 2015). Because of ADA's involvement in different health disorders, the development of ADA inhibitors as feasible therapeutic agents has been considered in many studies (Cristalli et al., 2001; Saboury et al., 2003, 2004, 2005; Ataie et al., 2004, 2007; Terasaka et al., 2004a,b; Da Settimo et al., 2005; Ajloo et al.,
2007; Ujjinamatada et al., 2008; La Motta et al., 2009; Bazl et al., 2012). Recently, ADA inhibitors have been proposed in perinatal hypoxia-ischemia brain injury treatment (Pimentel et al., 2013).

Polyvalent metal cations such as copper, zinc, and iron are found in high concentrations in senile plaques in $\mathrm{AD}$ patients' brain (Smith et al., 1997; Lovell et al., 1998; Sayre et al., 2000; Suh et al., 2000; Dong et al., 2003; Miller et al., 2006). Furthermore, some studies in mouse models of $\mathrm{AD}$ revealed that in spite of accumulation of copper in senile plaques in the mouse models with neurodegeneration including $5 \times$ FAD and CVN (Bourassa et al., 2013), no copper accumulation is observed in PSAPP mouse model with slight neurodegeneration (Bourassa et al., 2013; James et al., 2017). Considerable data point to dyshomeostasis of zinc and copper ions as the main factor of AD pathogenesis (Deibel et al., 1996; Lovell et al., 1998; Cherny et al., 1999, 2001; González et al., 1999; Huang et al., 1999, 2004; Sayre et al., 2000; Bayer et al., 2003; Phinney et al., 2003; Ritchie et al., 2003; Pajonk et al., 2005; Kessler et al., 2006; Ma et al., 2006; Maynard et al., 2006, 2002; Miller et al., 2006; Cater et al., 2008; Donnelly et al., 2008; Hung et al., 2009; Leskovjan et al., 2009; Hozumi et al., 2011; Mao et al., 2012; Arnal et al., 2013a,b; Pal et al., 2013; Singh et al., 2013) and indicate that copper metabolism proteins are associated with AD (Phinney et al., 2003; Southon et al., 2013; Pal et al., 2014).

Different authors have put forward various models of the toxicity of copper involvement in $\mathrm{AD}$. The most accredited one proposes the gain-of-function of $\beta$-amyloid (Bush et al., 2003; Bush and Tanzi, 2008) after binding $\mathrm{Cu}^{2+}$ (Multhaup et al., 1996). Alternative and more recent hypotheses (Lee et al., 2005; Cavaleri, 2015; Kepp, 2016) propose a protective role of $\beta$-amyloid against an excess of toxic metals within the brain, designating $\beta$-amyloid loss-of-function as a pathogenic process in the disease (Hua et al., 2011; Kepp, 2016). APP is thought to possess a normal function in metal export from neurons, and a putative loss of the soluble, functional $\beta$-amyloid monomer could cause copper build-up in the cell (Kepp, 2016).

Scientific evidence has shown that metal ion binding to $\beta$-amyloid accelerates amyloid aggregation, which could finally damage the neurons in AD (Pithadia and Lim, 2012). The involvement of copper in $\mathrm{AD}$ is controversial, as some studies show copper deficiency in $\mathrm{AD}$, and consequently a need to enhance copper levels (Borchardt et al., 1999; Kessler et al., 2005, 2008a,b; Exley, 2006; Jiao and Yang, 2007; Vural et al., 2010; Kaden et al., 2011; Exley et al., 2012), while other data point to copper overload and therefore a need to reduce copper levels (Cherny et al., 2001; Sparks et al., 2006; Hua et al., 2011; Luo et al., 2011; Ceccom et al., 2012; Eskici and Axelsen, 2012; Brewer, 2014; Squitti et al., 2014b; Yu et al., 2015). An aberrant copper homeostasis with an increase in the labile pool of copper and a decrease in the copper bound to protein is the main up-dated interpretation (Kepp, 2016; Squitti et al., 2016). In this paper, the role of metal ions, particularly copper, in $\mathrm{AD}$ is reviewed and discussed. 


\section{COPPER ION TOXICITY IN AD}

The key event in $\mathrm{AD}$ is the formation of fibrils and plaques in $\mathrm{AD}$ patients' brain. Plaques are mainly made of $\beta$-amyloid peptide, the natural peptide that is produced in the brain and exists at nanomolar concentration levels in cerebrospinal fluid (CSF) and serum (Masters et al., 1985; Vigo-Pelfrey et al., 1993). On the other hand, a high concentration of trace metals, including copper, is observed in amyloid plaques (Miller et al., 2006). Interestingly, some data show that copper distribution in the brain does not correspond to $\beta$-amyloid plaques distribution in TASTPM mice model (Torres et al., 2016) with plaque pathology but not appreciable neuronal loss (Howlett et al., 2004). Copper is a necessary trace metal in nervous system development since disruption of its homeostasis leads to neurodegenerative disorders like Menkes and Wilson's diseases (Waggoner et al., 1999). $\mathrm{Cu}^{2+}$ ions bind to $\beta$-amyloid peptides with high affinity (Atwood et al., 2000; Sarell et al., 2009; Barritt and Viles, 2015; Mital et al., 2015; Drew, 2017) and increase the proportions of $\beta$-sheet and $\alpha$-helix structures in amyloid peptides, which can be responsible for $\beta$-amyloid aggregation (Dai et al., 2006). Various concentrations of $\mathrm{Cu}^{2+}$ ions enhance fibril formation while binding of copper ions to $\beta$-amyloid noticeably increases its toxicity for cells (Dai et al., 2006; Sarell et al., 2010). In addition, substoichiometric concentrations of $\mathrm{Cu}^{2+}$ are more toxic to cells (Sarell et al., 2010).

Fibril formation is highly $\mathrm{pH}$-dependent and $\mathrm{Cu}^{2+}$ ions cause it to occur at physiological $\mathrm{pH}$. However, the formation of amorphous aggregates dominates in acidic conditions (Jun et al., 2009; Sarell, 2010; Lv et al., 2013). In a proton-rich environment, $\beta$-amyloid $\left(A \beta_{40}\right)$ possesses two copper binding sites, and its second bound $\mathrm{Cu}^{2+}$ ion causes the formation of amorphous aggregates by preventing the conformational transition of $\beta$-amyloid into amyloid fibrils (Jun et al., 2009).

The production of Reactive Oxygen Species (ROS) is a key factor in $\beta$-amyloid toxicity toward neurons, which is dependent on metal ion redox properties. Copper ions in complex with $\beta$-amyloid fibrils produce hydrogen peroxide, in the presence of biological reducing agents (Parthasarathy et al., 2014). When the ratio of copper to peptide increases, hydrogen peroxide levels and the production of hydroxyl radicals increase, and the morphology of aggregates changes from fibrillar to amorphous (Mayes et al., 2014). Although previous studies have presented ROS as fatal molecules provoking neurodegeneration, the accumulated evidence shows that some ROS act as essential molecules in processes underlying cognition and memory formation (Klann, 1998; Yermolaieva et al., 2000; Knapp and Klann, 2002a,b; Kamsler and Segal, 2003, 2004; Hu et al., 2006; Kishida and Klann, 2007). On the other hand, some results imply that the copperamyloid complex produces fewer ROS than free copper ions (Nakamura et al., 2007). According to in vitro data, oligomeric and fibrillar forms of $\beta$-amyloid inhibit $\mathrm{H}_{2} \mathrm{O}_{2}$ generation at higher concentrations of $\mathrm{Cu}^{2+}$. In addition, the fibrillar form generates less $\mathrm{H}_{2} \mathrm{O}_{2}$ than the oligomeric form (Fang et al., 2010).

Copper toxicity in $\mathrm{AD}$ brains is attributed to the oxidized form of copper ions, i.e., $\mathrm{Cu}^{2+}$, (Brewer, 2015; Greenough et al., 2016). In contrast, other data show that copper ions are only transported in their reduced form, i.e., $\mathrm{Cu}^{1+}$, (Macreadie, 2008). Some studies suggest that $\mathrm{Cu}^{2+}$ bypasses the liver (Brewer, 2015). Otherwise, some data show that the removal of $\mathrm{Cu}^{1+}$ from $\beta$-amyloid, hinders the formation of oligomers and prevents ROS production (Atrián-Blasco et al., 2015). A study of the affinity of the soluble copper-binding domain of the $\beta$-amyloid peptide for $\mathrm{Cu}^{1+}$ shows that it binds to $\beta$-amyloid stronger than $\mathrm{Cu}^{2+}$ suggesting $\mathrm{Cu}^{1+}$ is the relevant in vivo oxidation state (Feaga et al., 2011). Both $\mathrm{Cu}^{1+}$ and $\mathrm{Cu}^{2+}$ inhibit $\beta$-amyloid degradation by insulin-degrading enzyme, but $\mathrm{Cu}^{1+}$ cations act as irreversible inhibitors (Grasso et al., 2011). Copper ion by reduction from $\mathrm{Cu}^{2+}$ to $\mathrm{Cu}^{1+}$ protects proteins against free radicals (Deloncle and Guillard, 2014).

A meta-analysis (Schrag et al., 2011) and subsequent studies (James et al., 2012; Szabo et al., 2016) demonstrated that the concentration of total copper is decreased in the brain of $\mathrm{AD}$ patients, while the concentration of labile copper is increased in the most affected regions of the $\mathrm{AD}$ brain (James et al., 2012). In addition, AD cortical tissues (James et al., 2012) and the cortex of mice with Traumatic Brain Injury show an elevated binding capacity for $\mathrm{Cu}^{2+}$ (Peng et al., 2015). Another study shows that in $\mathrm{APP}^{\mathrm{sw} / 0}$ mouse model of $\mathrm{AD}$, which shows parenchymal plaques but no neuronal loss (Elder et al., 2010; Sasaguri et al., 2017), unlike in the control mouse in which the metal accumulates in the capillaries, copper ions accumulate in brain parenchyma. These ions could bind to $\beta$-amyloid and stimulate $\beta$-sheet conformation, aggregation, and toxicity (Singh et al., 2013).

In the "amyloid cascade hypothesis," plaque formation is a main event in $\mathrm{AD}$ pathology but it is sometimes preceded by neurodegeneration, and plaque clearance by immunization of $\mathrm{AD}$ patients does not prevent disease progression (Chui et al., 1999; Oddo et al., 2003; Holmes et al., 2008; Bayer and Wirths, 2010; Bittner et al., 2012; Wright et al., 2013; Xie et al., 2013; Jung et al., 2015). Moreover, some studies show that senile plaques exist in cognitively normal people (Jack et al., 2010; Sperling et al., 2011; Swerdlow, 2011; Esparza et al., 2013) and, despite an equivalent plaque presence, the concentration of brain amyloid oligomers is higher in $\mathrm{AD}$ patients than in normal cases. The "Toxic oligomers hypothesis" explains these events by suggesting that small, diffusible oligomers are responsible for toxicity, and not the amyloid plaques (Naylor et al., 2008; Sarell, 2010). The oligomers derived from cell culture have unusually high chemical stability and resist degradation into monomers by various degrading agents, supporting the existence of covalent cross-links between the oligomers (Podlisny et al., 1995; Walsh et al., 2002; Lesné et al., 2006; Naylor et al., 2008). Based on in vitro experiments, $\mathrm{Cu}^{2+}$ binding to $\beta$-amyloid can lead to the formation of dityrosine-linked dimers of $\beta$-amyloids found in AD (Atwood et al., 2004; Haeffner et al., 2005; Bush and Tanzi, 2008; Streltsov et al., 2008; Al-Hilaly et al., 2013). In the presence of $\mathrm{Cu}^{2+}$, the dimer conformation changes from parallel to antiparallel and is stabilized by the occupied copper binding sites (Hane et al., 2013). However, the same authors showed later that $\mathrm{Cu}^{2+}$ at nanomolar concentrations has no effect on peptidepeptide affinity in the amyloid dimer (Hane et al., 2016). Other authors have demonstrated that binding of $\mathrm{Cu}^{2+}$ ions induces 


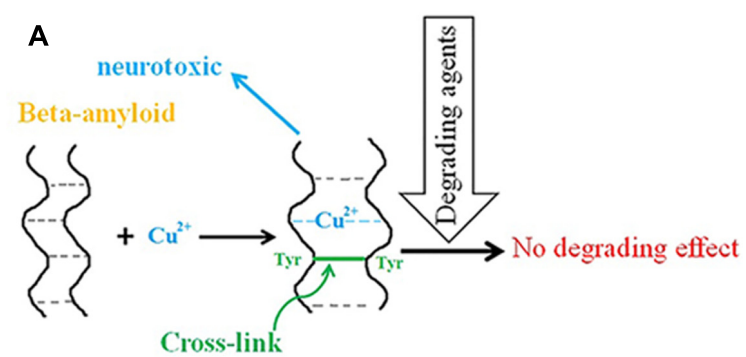

B

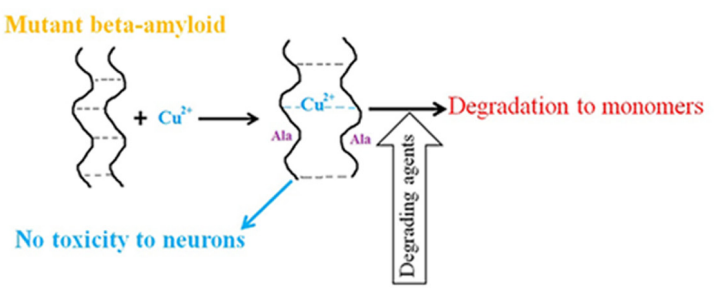

FIGURE 1 | The role of copper in $\beta$-amyloid neurotoxicity in AD. (A) Copper binding to $\beta$-amyloid peptides leads to the formation of dityrosine-linked $\beta$-amyloid dimers, which resist degradation into monomers and have neurotoxic properties. (B) Mutant $\beta$-amyloids (Tyr to Ala) in the presence of copper ions have no toxicity effect on neurons and degrade to monomers by degrading agents.

structural changes in the amyloid dimer resulting in N-termini interactions within it ( $\mathrm{Lv}$ et al., 2013). The mutant dimer that is unable to produce cross-links provides supporting evidence for the toxicity of $\mathrm{Cu}^{2+}$ cross-linked dimers because the mutant dimer's properties are the same as those of the wild type dimer except that it has no neurotoxicity (Barnham, 2004; Figure 1). In addition, other studies suggest that the toxicity of the crosslinked dimer is due to enhanced membrane binding (Ciccotosto et al., 2004).

Elimination of $\mathrm{Cu}^{2+}$ from $\beta$-amyloid prevents amyloid aggregation in vitro (Wu et al., 2008; Behbehani et al., 2012), and promotes $\beta$-amyloid degradation, and prevents $\mathrm{H}_{2} \mathrm{O}_{2}$ formation. Hence, it also decreases cell mortality (Wu et al., 2008). Because of these positive effects of copper elimination, some studies have targeted copper chelators as suitable drugs (Moret et al., 2006; Geng et al., 2012; Nguyen et al., 2014; Savelieff et al., 2014; HauserDavis et al., 2015; Hung et al., 2015; Yang et al., 2016). However, the most recently published review on copper chelation therapy states that the results in human clinical trials are discouraging (Drew, 2017), even though some authors have refuted this interpretation (Squitti et al., 2017a). Furthermore, studies in Tg2576 mouse model of AD, which shows parenchymal plaques but no neuronal loss (Elder et al., 2010; Sasaguri et al., 2017), show that although the use of chelator helps to prevent $A D$, it is inefficient in $\mathrm{AD}$ treatment suggesting that systemic copper removal is useful only in the early stages of the disease (Quinn et al., 2010). Interestingly, there is some evidence that making changes in brain copper uptake in the primary stages can have a considerable effect on amyloid pathology (Lang et al., 2013).

Until 2012, a number of ambiguous results published previously fueled a debate about copper levels in AD patients. Overall, six meta-analyses have been carried out in the last 6 years to evaluate copper concentrations in $\mathrm{AD}$ in different biological matrices (serum, plasma, and cerebrospinal fluid). These meta-analyses, combining data collected from studies published between 1984 and 2017 (Bucossi et al., 2011; Ventriglia et al., 2012; Schrag et al., 2013; Squitti et al., 2014a; Wang et al., 2015; Li et al., 2017), provide unequivocal results: total copper (Bucossi et al., 2011; Ventriglia et al., 2012; Schrag et al., 2013; Squitti et al., 2014a; Wang et al., 2015; Li et al., 2017) and "free" copper (Squitti et al., 2014a) are higher in the serumplasma of $\mathrm{AD}$ patients in comparison with healthy controls. More specifically, the large stand most recent meta-analysis (total pool of subjects analyzed: $2128 \mathrm{AD}$ vs. 2889 healthy controls) includes a total of 35 studies: 18 report an increase, 14 no difference, and one a decrease in values of copper in the serum-plasma in AD compared to healthy controls (Li et al., 2017). Three additional studies appeared after the publication of this consensus result (Guan et al., 2017; Pu et al., 2017; Talwar et al., 2017), reporting increased concentrations of $\mathrm{Cu}^{2+}$ in $\mathrm{AD}$ patients vs. controls.

Recent studies have contributed to unraveling further the initial controversy, demonstrating that the increased concentration of serum copper in $\mathrm{AD}$ can be explained by the increased concentrations of the plasma fraction of the "free" copper pool in the blood, which is detected in only $50-60 \%$ of AD patients (Squitti et al., 2016; Szabo et al., 2016; Tecchio et al., 2016; Talwar et al., 2017). An older study also indicated that serum copper concentration rises in a special type of AD (González et al., 1999). Some studies have proposed a genetic basis for this AD subtype as an explanation of this observation (González et al., 1999; Liu et al., 2013; Squitti et al., 2013, 2017b; Mercer et al., 2017).

\section{BRAIN COPPER DEFICIENCY IN AD}

A significant reduction in copper ion levels is observed in the hippocampus and amygdale areas of $\mathrm{AD}$ patients compared to age-matched control subjects (Deibel et al., 1996). In addition, a reduction in net copper is found in the brain of TgCRND8 AD mice model (Phinney et al., 2003), and this model exhibits parenchymal amyloid deposition but no neuronal loss (Sasaguri et al., 2017). As mentioned above, a meta-analysis indicates that copper is significantly decreased in the brain of $\mathrm{AD}$ patients (Schrag et al., 2011). An analysis of the human brains of deceased patients with dementia concludes that defective regions have a very low copper content (Pickart et al., 2017). The copper content of aged human brains has a significant negative correlation with the degree of severity of amyloid plaques (Exley et al., 2012). Based on the results showing a significant reduction in copper ion in $\mathrm{AD}$ patients compared to controls (Giacoppo et al., 2014), it has been hypothesized that $\mathrm{AD}$ is a result of copper deficiency (Klevay, 2008). An alternative, and more comprehensive, interpretation, which can explain the copper 
quantification results of meta-analyses in serum-plasma and the meta-analysis in the brain, is that the copper decrease in the brain is a sign of an aberrant copper homeostasis, which resembles Wilson's disease (Fujiwara et al., 2006). Interestingly, some data indicate that copper deficiency in $\mathrm{AD}$ patients is independent of their diet (Giacoppo et al., 2014).

In the presence and absence of copper, APP molecules are cleaved in non-amyloidogenic and amyloidogenic pathways, respectively. The latter pathway results in amyloid production. Some data show that copper ions inhibit amyloid production by interacting with a $\gamma$-secretase complex (Gerber et al., 2017) or by affecting APP dimerization (Kong et al., 2008). Otherwise, copper ions enhance APP exposure on the cell surface by both increasing its exocytosis and decreasing its endocytosis (Acevedo et al., 2011). Cu deficiency, as observed in AD patients, enhances $\beta$-amyloid production and accumulation by inducing the amyloidogenic processing of APP (Bayer et al., 2003). However, its molecular mechanism is still unclear (Wild et al., 2017).

The mutations in genes encoding proteins required for copper ion uptake in mammalian systems lead to early-onset familial $\mathrm{AD}$ (Southon et al., 2013). On the other hand, enhancement of intracellular copper levels through addition of dietary copper in APP/PS1 transgenic AD mice (Crouch et al., 2009) and APP23 transgenic mice (Bayer et al., 2003) with parenchymal plaques but no neuronal loss (Elder et al., 2010; Sasaguri et al., 2017), causes a reduction in $\mathrm{AD}$ pathology. Based on the report of low brain copper in several neurodegenerative disorders, impairment in copper protection against free radicals has been proposed as the main cause of these disorders (Deloncle and Guillard, 2014).

\section{COPPER AND ZINC IONS IN AD}

A significant elevation in $\mathrm{Zn}^{2+}$ is found in the $\mathrm{AD}$ hippocampus and amygdale area (Deibel et al., 1996), and in the AD neuropil compared to controls (Lovell et al., 1998), although some data indicate an elevation in $\mathrm{Zn}^{2+}$ content in the $\mathrm{AD}$ brain cortex (Religa et al., 2006). Accordingly, a meta-analysis revealed no significant changes in zinc content in the AD neocortex (Schrag et al., 2011). Nevertheless, three meta-analyses (Ventriglia et al., 2015; Wang et al., 2015; Li et al., 2017) were recently carried out on plasma and serum zinc levels in AD patients and healthy controls. One study (Ventriglia et al., 2015) (the pooled sample size included 777 AD vs. 1728 healthy controls) analyzed a total of 16 studies and concludes that AD patients show a decrease in serum zinc levels compared to healthy controls. Ventriglia et al.' (2015) study (the pooled sample size included 287 AD vs. 166 healthy controls) analyzed a total of five studies on plasma zinc: two indicate a decrease and three no significant differences in plasma zinc in $\mathrm{AD}$ patients compared to controls. The other study (Wang et al., 2015) (the pool of subjects included $862 \mathrm{AD}$ patients vs. 1705 controls) analyzed a total of 17 studies: 10 indicate a decrease, and seven no significant differences in serum zinc in $\mathrm{AD}$ patients compared to controls. The most recent meta-analysis by Li et al. (2017) analyzed 22 studies with a total pool of 1027 patients with AD and 1949 healthy controls: three studies indicate
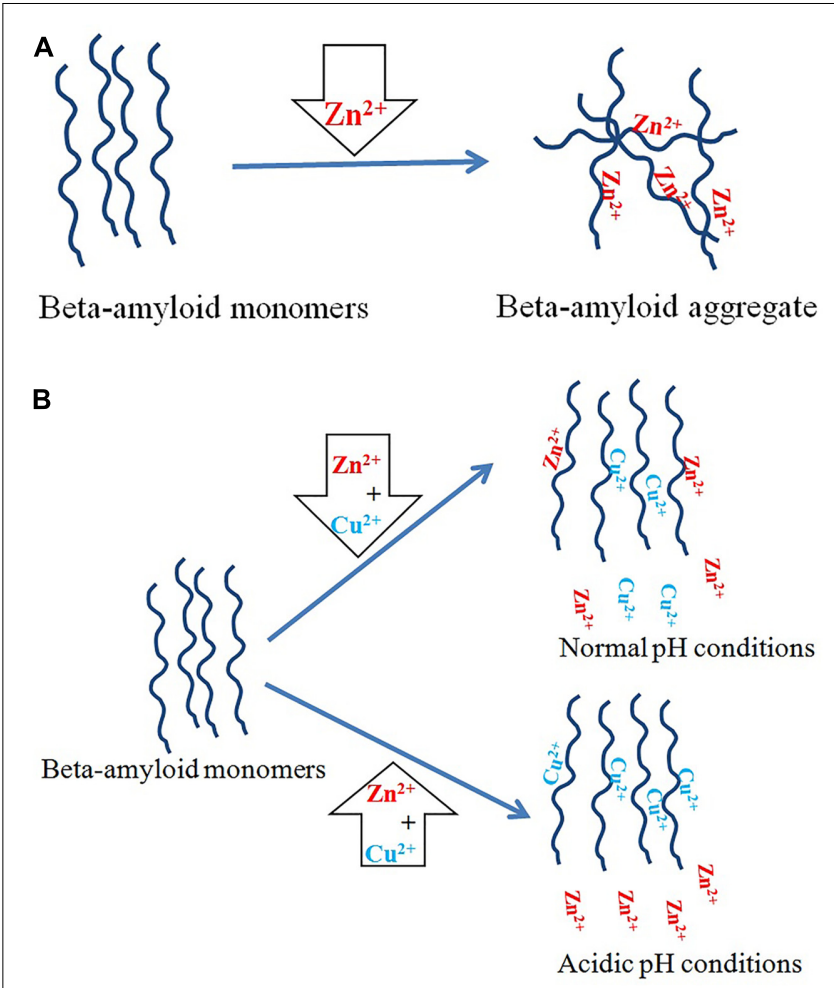

FIGURE 2 | Copper and zinc ions in AD. (A) Zinc ions promote $\beta$-amyloid aggregation. (B) Copper ions have an inhibitory effect on aggregation induced by zinc ions. Under physiological conditions, $\beta$-amyloid binds the same ratio of copper and zinc ions, but in acidic $\mathrm{pH}$ copper ions replace zinc ions overall.

an increase, 18 studies a decrease, and one study no differences in serum zinc between $\mathrm{AD}$ and healthy controls. Interestingly, an older study found that a rise in serum $\mathrm{Zn}^{2+}$ occurs in a special type of AD (González et al., 1999). As the absence of fibrinogen in serum is the main difference between serum and plasma compositions and fibrinogen- $\beta$-amyloid interactions are involved in AD progression (Cortes-Canteli et al., 2012; Derakhshankhah et al., 2016), it is likely that the reduction in serum $\mathrm{Zn}^{2+}$ in AD patients is due to its interactions with fibrinogen. The rise in zinc levels is accompanied by a rise in tissue amyloid levels (Religa et al., 2006). AD brain tissue contains hot spots of metal ions especially enriched by copper and zinc ions. In 2006, it was reported for the first time that $\beta$-amyloid plaques and hot spots of accumulated metal ions co-localize (Miller et al., 2006).

It has been suggested that zinc ions induce $\beta$-amyloid aggregation in vitro whereas $\mathrm{Cu}^{2+}$ ions inhibit it through competing with zinc for histidine residues. The strongest inhibitory effect occurs at a copper: $\beta$-amyloid molar ratio of about four. Above this value, copper ions themselves induce aggregation (Suzuki et al., 2001). Interestingly, previous studies have shown that $\beta$-amyloid binds to three or four $\mathrm{Cu}^{2+}$ ions at pH 7.0 (Atwood et al., 1998). Studies on synthetic $\mathrm{A} \beta(1-40)$ and $\mathrm{A} \beta(1-42)$ peptides show that at physiological $\mathrm{pH}, \beta$-amyloid binds the same ratio of copper and zinc ions, whereas in acidic conditions copper ions replace zinc ions (Figure 2; Atwood et al., 
2000; Roberts et al., 2012). $\mathrm{Cu}^{2+}$ and $\mathrm{Zn}^{2+}$ ions inhibit $\beta$-amyloid fibrillization, promoting instead the formation of non-fibrillar aggregates in vitro. In addition, zinc ions have a threefold stronger inhibitory effect than copper ions (Tõugu et al., 2009). Both $\mathrm{Cu}^{2+}$ and $\mathrm{Zn}^{2}$ ions prevent the formation of soluble fibrils if incubated with $A \beta(1-42)$ in vitro (Bolognin et al., 2011). Some authors have also reported that small, soluble oligomers play the main role in $\beta$-amyloid neurotoxicity (Tabner et al., 2011). $\mathrm{Cu}^{2+}$ ions form stable and soluble 1:1 complexes with $\beta$-amyloid $\left(\mathrm{A} \beta_{40}\right)$ while $\mathrm{Zn}^{2+}$ ions cause their partial aggregation (Tõugu et al., 2008). $\mathrm{Cu}^{2+}$-induced aggregates are toxic to neurons only in the presence of ascorbate, while monomers and zinc-induced aggregates are not toxic (Tõugu et al., 2009).

The role of zinc supplementation in $\mathrm{AD}$ remains controversial according to a systematic review in 2012 reporting that $\mathrm{Zn}^{2+}$ in the diet has no effect on cognitive decline (Loef et al., 2012) even though the Zenith and the Zincage studies suggested some effects (Simpson et al., 2005; Marcellini et al., 2006; Maylor et al., 2006). However, 3xTg-AD mice model with background neuropathology similar to AD patients (Sasaguri et al., 2017) displayed a delay in memory impairment (Corona et al., 2010). Furthermore, Tg2576, TgCRND8 and CRND8/E4 models exhibited a potentiationin memory impairment (Linkous et al., 2009; Railey et al., 2011; Flinn et al., 2014). Moreover, Tg2576 mice and Sprague Dawley rats showed a lower brain copper and amyloid burden (Harris et al., 2014), and a higher cognitive performance, respectively (Sandusky-Beltran et al., 2017).

Selective release of $\mathrm{Cu}^{2+}$ and $\mathrm{Zn}^{2+}$ ions inside the cells by complexes can decrease the level of $\beta$-amyloids (Donnelly et al., 2008). B-amyloid peptides in the presence of physiological concentrations of copper and zinc ions are degraded but at higher concentrations of these cations they aggregate (Strozyk et al., 2009). In agreement with this finding, the use of a copper-zinc chelator rapidly causes a considerable decrease in the deposition of brain amyloid in APP2576 transgenic mice (Cherny et al., 2001). Other authors suggest that the addition of chelators to $\beta$-amyloid aggregates induces their rapid fibrillization in vitro. In addition, a long incubation of non-fibrillar aggregates transforms them into fibrillar forms (Tõugu et al., 2009). These findings confirm that the fibrillar form of $\beta$-amyloid is its most stable state (Tõugu et al., 2009; Breydo et al., 2016). $\mathrm{Zn}^{2+}$ and $\mathrm{Cu}^{2+}$ ions induce refolding of $\beta$-sheets into $\alpha$-helix structures leading to oligomerization and membrane penetration of amyloid peptides (Curtain et al., 2001). Copper and zinc ions both induce a $\beta$-amyloid conformational change but zinc has a greater effect (Yao et al., 2012).

\section{IRON IONS IN AD}

Iron is a redox active metal and its brain level varies according to specific regions of the brain. Commonly, the brain areas responsible for motor functions are found to have higher iron concentrations than non-motor related areas (Kozlowski et al., 2012). Iron also has a high concentration at the periphery of amyloid plaques (Greenough et al., 2013). Nevertheless, there is controversy about the level of iron outside plaques in the AD brain (Schrag et al., 2011). Contrary to copper and zinc, very few structural studies have been reported on iron coordination to $\beta$-amyloid (Hureau, 2012). While copper and zinc co-purify with $\beta$-amyloid extracted from plaques, iron does not co-localize within $\beta$-amyloid deposits (GrundkeIqbal et al., 1990; Quintana et al., 2006; Kozlowski et al., 2012) and in vitro studies have shown that $\beta$-amyloid binds to iron with low affinity (Viles, 2012; Greenough et al., 2013). After Louis Goodman's case studies performed in the 1950s, a relationship between regions of $\mathrm{AD}$ pathology and iron accumulation was proposed (Everett et al., 2014). Some data show that $\beta$-amyloid reduces $\mathrm{Fe}^{3+}-\mathrm{Fe}^{2+}$ in solution in vitro (Khan et al., 2006; Everett et al., 2014). While some authors argue that the direct coordination of $\mathrm{Fe}^{3+}$ to $\beta$-amyloid is impossible at natural $\mathrm{pH}$ and that $\mathrm{Fe}^{2+}$ is air-sensitive and oxidizes to $\mathrm{Fe}^{3+}$ during measurements (Hureau, 2012), others report a potential pro-aggregating function for $\mathrm{Fe}^{2+}$ and $\mathrm{Fe}^{3+}$ (Masters and Selkoe, 2012) and some data show a higher affinity for $\beta$-amyloid to $\mathrm{Fe}^{2+}$ relative to transferrin (Jiang et al., 2009). Three meta-analyses have been carried out in the last 4 years to assess iron concentrations in $\mathrm{AD}$ in serum, cerebrospinal fluid, and brain (Tao et al., 2014; Wang et al., 2015; Li et al., 2017). Tao et al.'s (2014) meta-analysis (total pool of subjects analyzed: 1813 AD vs. 2401 healthy controls) includes a total of 43 studies; 21 consider serum iron; seven consider CSF iron and 19 investigate iron in various brain areas in $\mathrm{AD}$. Their results shows that serum iron significantly decreases in $\mathrm{AD}$ compared to controls. CSF iron shows no difference while some specific brain areas show an increase in iron concentration. Wang et al.'s (2015) meta-analysis (total pool of subjects analyzed: $1084 \mathrm{AD}$ vs. 1319 healthy controls) includes a total of 18 studies showing no difference in serum iron but, after exclusion of the study producing high heterogeneity, their results conclude that serum iron levels are significantly lower in AD subjects. Li et al.'s (2017) meta-analysis (total pool of subjects analyzed: 1379 AD vs. 1664 healthy controls) includes 25 studies that show overall no significant difference in serum iron between $\mathrm{AD}$ and controls but, after excluding two studies with high heterogeneity, serum iron is significantly lower in AD cases.

\section{COPPER AND LIPID RAFTS IN AD}

There is considerable evidence that the amyloidogenic pathway takes place in lipid rafts, which are specific membrane domains enriched in cholesterol. The enzymes that cleave APP to $\beta$-amyloid peptides are found in lipid rafts (Riddell et al., 2001; Hung et al., 2009). Cellular copper deficiency results in an accumulation of copper ions in cholesterol-rich lipid rafts. In fact, the copper level in lipid rafts is inversely related to cellular copper, which results in enhanced copper-amyloid complex formation under copper deficiency conditions in AD (Cater et al., 2008; Hung et al., 2009).

Clearly, diet is a critical factor in the progression of AD. Several studies indicate the key role of fat in $A D$ (Grant, 1997; Sparks and Schreurs, 2003; Morris et al., 2006; 
A

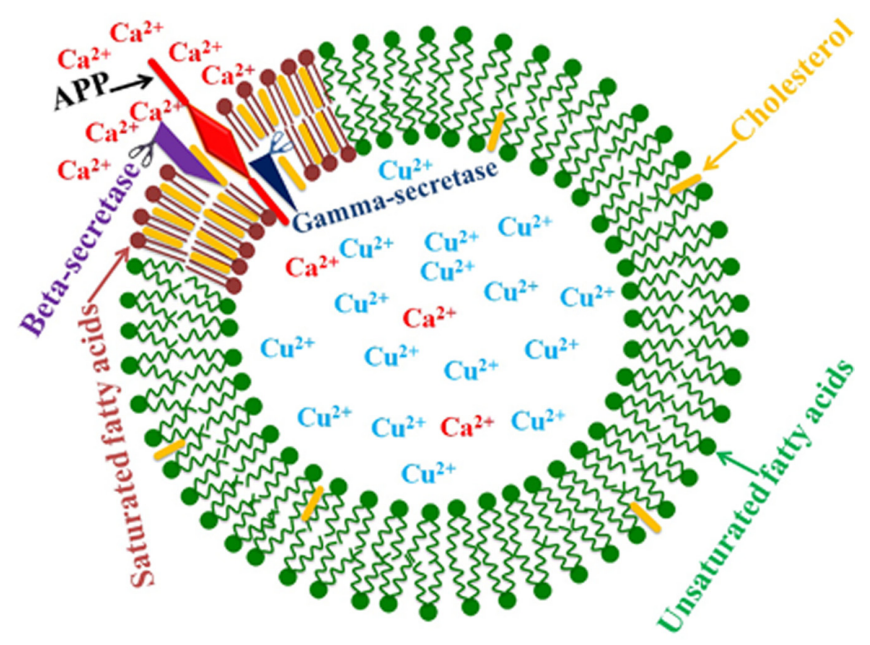

B

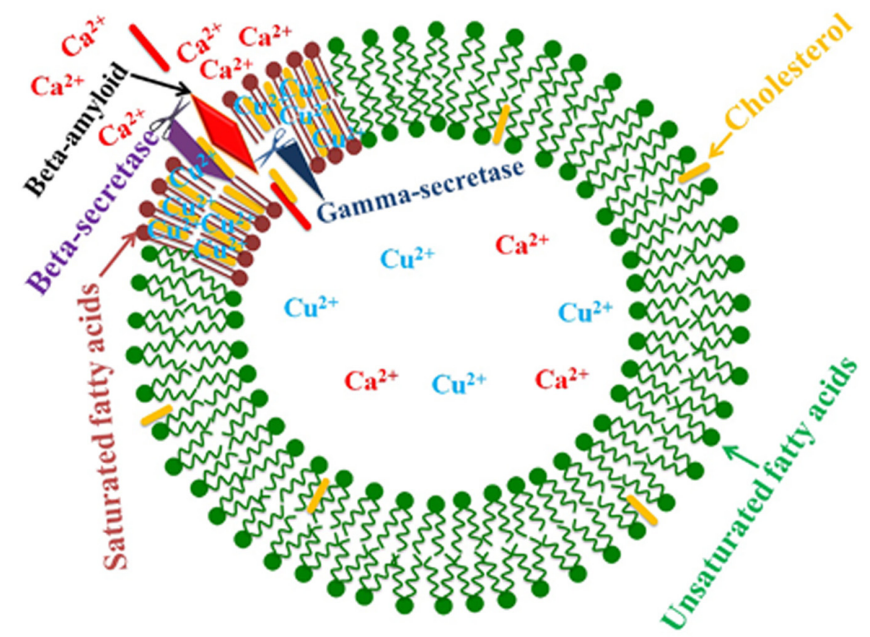

C

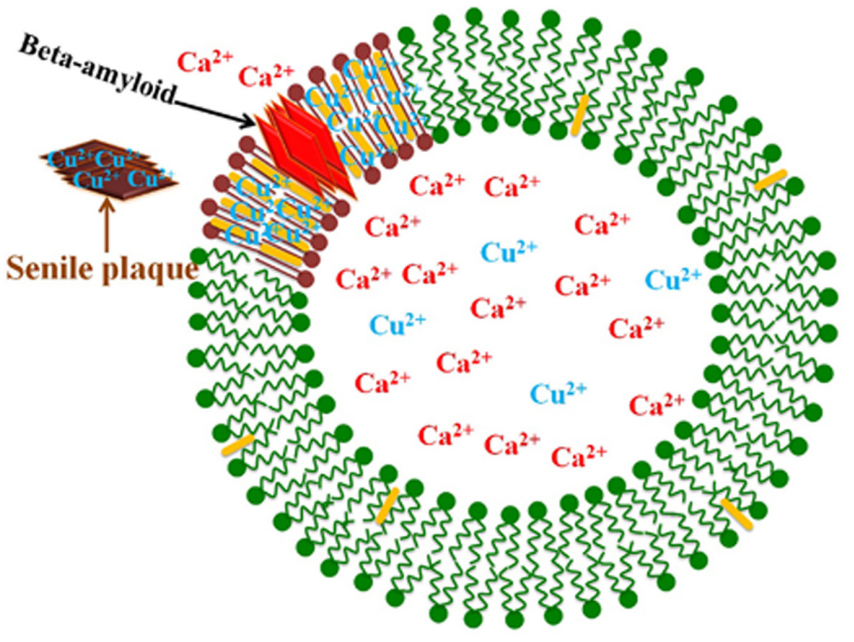

FIGURE 3 | Schematic diagram of the relationship between copper and lipid rafts in AD. (A) The enzymes that cleave APP to $\beta$-amyloid peptides are found in lipid rafts. (B) Cellular copper deficiency results in copper ions accumulating in cholesterol-rich lipid rafts, and $\beta$-amyloid production increases because of greater enzyme activity due to a rising copper concentration. (C) $\beta$-amyloid peptides compose the oligomeric pores in membranes via the cholesterol-binding domain. These pores are calcium channels that disrupt calcium homeostasis in neural cells. 
Brewer, 2012). The effective role of $\mathrm{Cu}^{2+}$ and cholesterol overload in neurodegeneration has been reported (Arnal et al., 2013b; Wong et al., 2014). In rats treated with copper and cholesterol, a significant change in visuo-spatial memory is detected (Arnal et al., 2013b) while the administration of dietary cholesterol plus copper-supplemented drinking water (in the form of copper sulfate) induces an accumulation of $\beta$-amyloid in rabbit brain (Larry, 2004). The binding of $\mathrm{Cu}^{2+}$ ions to $\beta$-amyloid causes oxidation of cholesterol, and the generation of $\mathrm{H}_{2} \mathrm{O}_{2}$ (Hung et al., 2009) and other lipid peroxidation products accumulating in $\mathrm{AD}$ patients' brain (Murray et al., 2007) and in Tg2576 transgenic mouse model (Puglielli et al., 2005). In fact, previous unsuccessful therapeutic attempts and recent findings regarding $\beta$-amyloid accumulation at lipid rafts have led to a new hypothesis that neurotoxicity in $\mathrm{AD}$ is the result of the association of small soluble amyloid oligomers with the plasma membrane (Drolle et al., 2014; Kotler et al., 2014; Arbor et al., 2016). B-amyloid membrane binding is mediated by its interactions with phosphatidylserine (Ciccotosto et al., 2011).

A highly toxic isoform of $\beta$-amyloid that accumulates in $\mathrm{AD}$ patients' brain has a great capacity to induce lipid peroxidation. It also alters the calcium influx by binding to cell membranes. This isoform does not lead to an increase in ROS but it causes instead a reduction in plasma membrane integrity and an increase in dityrosine- $\beta$-amyloid oligomers (Gunn et al., 2016). Other studies have suggested that the toxicity of the cross-linked dimer is due to enhanced membrane binding (Ciccotosto et al., 2004).

Simulation experiments show that increased cell membrane cholesterol results in some changes in the membrane; namely, an enhancement of surface hydrophobicity and a reduction in bilayer mobility. These membrane changes induce amyloid binding to the cell membrane and cause $\beta$-amyloid to refold into a helical or unstructured form. B-amyloid is stabilized on the membrane surface or inserted into the bilayer with the help of calcium ions ( $\mathrm{Yu}$ and Zheng, 2012). In fact, $\beta$-amyloid peptides compose the oligomeric pores in the membrane via the cholesterol-binding domain (Lashuel et al., 2002; Di Scala et al., 2014). Channel formation is cholesterol-dependent and occurs in the presence of at least 30\% cholesterol in lipid bilayer membranes. These pores are ion channels that disrupt calcium homeostasis in neural cells and have led to the return of the "calcium hypothesis" of AD (Di Scala et al., 2014, 2016; Figure 3). In the absence of copper, $\beta$-amyloids are cleared to the blood even if there are increased cholesterol levels, while in the presence of copper $\beta$-amyloid accumulate in the brain (Sparks, 2007). Otherwise, copper ions in the absence of $\beta$-amyloid are not toxic to cells (Sarell et al., 2010).

\section{REFERENCES}

Acevedo, K. M., Hung, Y. H., Dalziel, A. H., Li, Q. X., Laughton, K., Wikhe, K., et al. (2011). Copper promotes the trafficking of the amyloid precursor protein. J. Biol. Chem. 286, 8252-8262. doi: 10.1074/jbc.M110.128512

\section{CONCLUSION}

Alzheimer's disease is a progressive degenerative disease characterized by the presence of senile plaques in the AD patient's brain. It is a multifactorial disease with a number of genetic and environmental factors likely involved. Previous studies have identified these plaques as toxic elements in AD. However, other studies have demonstrated that $20-40 \%$ of healthy people possess senile plaques in their brains (Jack et al., 2010). Moreover, cell death sometimes precedes plaque formation. A number of studies have focused on ROS generation by a copper-amyloid complex and propose ROS as toxic elements in AD. Still other authors have shown that ROS are the basis of memory formation. In addition, fibrils and oligomers at higher copper ion concentrations inhibit the production of ROS. As an alternative, the toxic oligomers hypothesis seems strong, showing that soluble oligomers interact with cell membranes, inducing in them the formation of calcium channels. Collectively, it seems that a disruption of copper control mechanisms occurs in $\mathrm{AD}$, affecting the compartmentalization of the metal in different tissues and organs. Some authors have observed that the increased levels of the labile pool of copper in the brain (James et al., 2012) and in the periphery (Squitti et al., 2014a) bring about a deficiency of copper in the brain and an increase in the labile pool of copper in the brain and in "free copper" in the blood. This is the picture implied by the conditions of Wilson's disease (Fujiwara et al., 2006). A possible interpretation is that a copper deficiency in brain cells is harmful because of amyloid production, and then copper deficiency leads to a rise in copper levels on lipid rafts. In conditions of copper deficiency, the amyloid-copper complex increases in lipid rafts because of higher levels of both copper and amyloid as well as the high affinity of amyloid peptides for copper. Copper ion binding and proximity to the cell membrane induce the refolding of amyloid peptides, and finally their oligomerization and interactions with cell membranes. The root of copper deficiency in the brain cells seems to be an important factor in AD. Since it is accompanied by copper enrichment in lipid rafts, one can argue that an elevation in lipid raft domains could lead to copper deficiency in the brain, thus targeting lipid rafts could be an effective therapeutic approach. Indeed, some data show that disrupting lipid rafts (by omega-3 fatty acids) delays the incidence of the disease (Cooper, 2003; Dannenberger et al., 2013; Arbor et al., 2016).

\section{AUTHOR CONTRIBUTIONS}

The review was written by SB with assistance and feedback from AS, RS, TH, and MS. All authors approved the final version of the manuscript.

Ajloo, D., Saboury, A. A., Haghi-Asli, N., Ataei-Jafarai, G., Moosavi-Movahedi, A. A., Ahmadi, M., et al. (2007). Kinetic, thermodynamic and statistical studies on the inhibition of adenosine deaminase by aspirin and diclofenac. J. Enzyme Inhib. Med. Chem. 22, 395-406. doi: 10.1080/147563607012 29085 
Al-Hilaly, Y. K., Williams, T. L., Stewart-Parker, M., Ford, L., Skaria, E., Cole, M., et al. (2013). A central role for dityrosine crosslinking of Amyloid- $\beta$ in Alzheimer's disease. Acta Neuropathol. Commun. 1:83. doi: 10.1186/20515960-1-83

Angulo, E., Casadó, V., Mallol, J., Canela, E. I., Viñals, F., Ferrer, I., et al. (2003). A1 adenosine receptors accumulate in neurodegenerative structures in Alzheimer disease and mediate both amyloid precursor protein processing and tau phosphorylation and translocation. Brain Pathol. 13, 440-451. doi: 10.1111/j.1750-3639.2003.tb00475.x

Arbor, S. C., Lafontaine, M., and Cumbay, M. (2016). Amyloid-beta Alzheimer targets - protein processing, lipid rafts, and amyloid-beta pores. Yale J. Biol. Med. 89, 5-21.

Armstrong, R. A. (2013). What causes Alzheimer's disease? Folia Neuropathol. 51, 169-188. doi: 10.5114/fn.2013.37702

Arnal, N., Castillo, O., De Alaniz, M. J. T., and Marra, C. A. (2013a). Effects of copper and/or cholesterol overload on mitochondrial function in a rat model of incipient neurodegeneration. Int. J. Alzheimers Dis. 2013:645379. doi: 10.1155/ 2013/645379

Arnal, N., Morel, G. R., De Alaniz, M. J. T., Castillo, O., and Marra, C. A. (2013b). Role of copper and cholesterol association in the neurodegenerative process. Int. J. Alzheimers Dis. 2013:414817. doi: 10.1155/2013/414817

Ataie, G., Bagheri, S., Divsalar, A., Saboury, A. A., Safarian, S., Namaki, S., et al. (2007). A kinetic comparison on the inhibition of adenosine deaminase by purine drugs. Iran. J. Pharm. Res. 6, 43-50.

Ataie, G., Safarian, S., Divsalar, A., Saboury, A. A., Moosavi-Movahedi, A. A., Ranjbar, B., et al. (2004). Kinetic and structural analysis of the inhibition of adenosine deaminase by acetaminophen. J. Enzyme Inhib. Med. Chem. 19, 71-78. doi: 10.1080/14756360310001632741

Atrián-Blasco, E., Cerrada, E., Conte-Daban, A., Testemale, D., Faller, P., Laguna, M., et al. (2015). Copper(I) targeting in the Alzheimer's disease context: a first example using the biocompatible PTA ligand. Metallomics 7, 1229-1232. doi: 10.1039/C5MT00077G

Atwood, C. S., Moir, R. D., Huang, X., Scarpa, R. C., Bacarra, N. M. E., Romano, D. M., et al. (1998). Dramatic aggregation of Alzheimer by Cu(II) is induced by conditions representing physiological acidosis. J. Biol. Chem. 273, 12817-12826. doi: $10.1074 /$ jbc.273.21.12817

Atwood, C. S., Perry, G., Zeng, H., Kato, Y., Jones, W. D., Ling, K. Q., et al. (2004). Copper mediates dityrosine cross-linking of Alzheimer's Amyloid- $\beta$. Biochemistry 43, 560-568. doi: 10.1021/bi0358824

Atwood, C. S., Scarpa, R. C., Huang, X., Moir, R. D., Jones, W. D., Fairlie, D. P., et al. (2000). Characterization of copper interactions with Alzheimer Amyloid $\beta$ peptides. J. Neurochem. 75, 1219-1233. doi: 10.1046/j.1471-4159.2000.075 1219.x

Barnham, K. J. (2004). Tyrosine gated electron transfer is key to the toxic mechanism of Alzheimer's disease -amyloid. FASEB J. 18, 1427-1429. doi: 10.1096/fj.04-1890fje

Barritt, J. D., and Viles, J. H. (2015). Truncated amyloid- $\beta_{(11-40 / 42)}$ from Alzheimer disease binds $\mathrm{Cu}^{2+}$ with a femtomolar affinity and influences fiber assembly. J. Biol. Chem. 290, 27791-27802. doi: 10.1074/jbc.M115. 684084

Bayer, T. A., Schafer, S., Simons, A., Kemmling, A., Kamer, T., Tepests, R., et al. (2003). Dietary Cu stabilizes brain superoxide dismutase 1 activity and reduces amyloid A production in APP23 transgenic mice. Proc. Natl. Acad. Sci. U.S.A. 100, 14187-14192. doi: 10.1073/pnas.2332818100

Bayer, T. A., and Wirths, O. (2010). Intracellular accumulation of amyloid-beta a predictor for synaptic dysfunction and neuron loss in Alzheimer's disease. Front. Aging Neurosci. 2:8. doi: 10.3389/fnagi.2010.00008

Bazl, R., Ganjali, M. R., Saboury, A., Foroumadi, A., Nourozi, P., and Amanlou, M. (2012). A new strategy based on pharmacophore-based virtual screening in adenosine deaminase inhibitors detection and in-vitro study. DARU J. Pharm. Sci. 20:64. doi: 10.1186/2008-2231-20-64

Behbehani, G. R., Barzegar, L., Mohebbian, M., and Saboury, A. A. (2012). A comparative interaction between copper ions with Alzheimer's amyloid peptide and human serum albumin. Bioinorg. Chem. Appl. 2012:208641. doi: $10.1155 / 2012 / 208641$

Bittner, T., Burgold, S., Dorostkar, M. M., Fuhrmann, M., Wegenast-Braun, B. M., Schmidt, B., et al. (2012). Amyloid plaque formation precedes dendritic spine loss. Acta Neuropathol. 124, 797-807. doi: 10.1007/s00401-012-1047-8
Boison, D. (2006). Adenosine kinase, epilepsy and stroke: mechanisms and therapies. Trends Pharmacol. Sci. 27, 652-658. doi: 10.1016/j.tips.2006.10.008

Bolognin, S., Messori, L., Drago, D., Gabbiani, C., Cendron, L., and Zatta, P. (2011). Aluminum, copper, iron and zinc differentially alter amyloid-A $\beta$ 1-42 aggregation and toxicity. Int. J. Biochem. Cell Biol. 43, 877-885. doi: 10.1016/j. biocel.2011.02.009

Borchardt, T., Camakaris, J., Cappai, R., Masters, C. L., Beyreuther, K., and Multhaup, G. (1999). Copper inhibits beta-amyloid production and stimulates the non-amyloidogenic pathway of amyloid-precursor-protein secretion. Biochem. J. 344(Pt 2), 461-467.

Bourassa, M. W., Leskovjan, A. C., Tappero, R. V., Farquhar, E. R., Colton, C. A., Van Nostrand, W. E., et al. (2013). Elevated copper in the amyloid plaques and iron in the cortex are observed in mouse models of Alzheimer's disease that exhibit neurodegeneration. Biomed. Spectrosc. Imaging 2, 129-139. doi: 10.3233/BSI-130041

Brewer, G. J. (2012). Copper excess, zinc deficiency, and cognition loss in Alzheimer's disease. Biofactors 38, 107-113. doi: 10.1002/biof. 1005

Brewer, G. J. (2014). Alzheimer's disease causation by copper toxicity and treatment with zinc. Front. Aging Neurosci. 6:92. doi: 10.3389/fnagi.2014.00092

Brewer, G. J. (2015). Divalent copper as a major triggering agent in Alzheimer's disease. J. Alzheimers Dis. 46, 593-604. doi: 10.3233/JAD-143123

Breydo, L., Kurouski, D., Rasool, S., Milton, S., Wu, J. W., Uversky, V. N., et al. (2016). Structural differences between amyloid beta oligomers. Biochem. Biophys. Res. Commun. 477, 700-705. doi: 10.1016/j.bbrc.2016. 06.122

Bucossi, S., Ventriglia, M., Panetta, V., Salustri, C., Pasqualetti, P., Mariani, S., et al. (2011). Copper in Alzheimer's disease: a meta-analysis of serum, plasma, and cerebrospinal fluid studies. J. Alzheimers Dis. 24, 175-185. doi: 10.3233/JAD2010-101473

Buée, L., Bussière, T., Buée-Scherrer, V., Delacourte, A., and Hof, P. R. (2000). Tau protein isoforms, phosphorylation and role in neurodegenerative disorders. Brain Res. Rev. 33, 95-130. doi: 10.1016/S0165-0173(00)00019-9

Bush, A. I., Masters, C. L., and Tanzi, R. E. (2003). Copper, -amyloid, and Alzheimer's disease: tapping a sensitive connection. Proc. Natl. Acad. Sci. U.S.A. 100, 11193-11194. doi: 10.1073/pnas.2135061100

Bush, A. I., and Tanzi, R. E. (2008). Therapeutics for Alzheimer's disease based on the metal hypothesis. Neurotherapeutics 5, 421-432. doi: 10.1016/j.nurt.2008. 05.001

Cater, M. A., McInnes, K. T., Li, Q.-X., Volitakis, I., Fontaine, S. L. A., Mercer, J. F. B., et al. (2008). Intracellular copper deficiency increases amyloid- $\beta$ secretion by diverse mechanisms. Biochem. J. 412, 141-152. doi: 10.1042/ BJ20080103

Cavaleri, F. (2015). Paradigm shift redefining molecular, metabolic and structural events in Alzheimer's disease involves a proposed contribution by transition metals. Defined lengthy preclinical stage provides new hope to circumvent advancement of disease- and age-related neurodegeneration. Med. Hypotheses 84, 460-469. doi: 10.1016/j.mehy.2015.01.044

Ceccom, J., Coslédan, F., Halley, H., Francès, B., Lassalle, J. M., and Meunier, B. (2012). Copper chelator induced efficient episodic memory recovery in a non-transgenic Alzheimer's mouse model. PLOS ONE 7:e43105. doi: 10.1371/ journal.pone.0043105

Cherny, R. A., Atwood, C. S., Xilinas, M. E., Gray, D. N., Jones, W. D., McLean, C. A., et al. (2001). Treatment with a copper-zinc chelator markedly and rapidly inhibits $\beta$-amyloid accumulation in Alzheimer's disease transgenic mice. Neuron 30, 665-676. doi: 10.1016/S0896-6273(01)00317-8

Cherny, R. A., Legg, J. T., McLean, C. A., Fairlie, D. P., Huang, X., Atwood, C. S., et al. (1999). Aqueous dissolution of Alzheimer's disease Abeta amyloid deposits by biometal depletion. J. Biol. Chem. 274, 23223-23228. doi: 10.1074/jbc.274.33. 23223

Chui, D. H., Tanahashi, H., Ozawa, K., Ikeda, S., Checler, F., Ueda, O., et al. (1999). Transgenic mice with Alzheimer presenilin 1 mutations show accelerated neurodegeneration without amyloid plaque formation. Nat. Med. 5, 560-564. doi: 10.1038/8438

Ciccotosto, G. D., Tew, D., Curtain, C. C., Smith, D., Carrington, D., Masters, C. L., et al. (2004). Enhanced toxicity and cellular binding of a modified amyloid $\beta$ peptide with a methionine to valine substitution. J. Biol. Chem. 279, 42528-42534. doi: 10.1074/jbc.M406465200 
Ciccotosto, G. D., Tew, D. J., Drew, S. C., Smith, D. G., Johanssen, T., Lal, V., et al. (2011). Stereospecific interactions are necessary for Alzheimer disease amyloid$\beta$ toxicity. Neurobiol. Aging 32, 235-248. doi: 10.1016/j.neurobiolaging.2009. 02.018

Cleveland, D. W., Hwo, S. Y., and Kirschner, M. W. (1977). Purification of tau, a microtubule-associated protein that induces assembly of microtubules from purified tubulin. J. Mol. Biol. 116, 207-225. doi: 10.1016/0022-2836(77) 90213-3

Conte-Daban, A., Day, A., Faller, P., and Hureau, C. (2016). How Zn can impede $\mathrm{Cu}$ detoxification by chelating agents in Alzheimer's disease: a proof-of-concept study. Dalton Trans. 45, 15671-15678. doi: 10.1039/C6DT02308H

Cooper, J. L. (2003). Dietary lipids in the aetiology of Alzheimer's disease. Drugs Aging 20, 399-418. doi: 10.2165/00002512-200320060-00001

Corodimas, K. P., and Tomita, H. (2001). Adenosine A1 receptor activation selectively impairs the acquisition of contextual fear conditioning in rats. Behav. Neurosci. 115, 1283-1290. doi: 10.1037/0735-7044.115.6.1283

Corona, C., Masciopinto, F., Silvestri, E., Del Viscovo, A., Lattanzio, R., La Sorda, R., et al. (2010). Dietary zinc supplementation of 3xTg-AD mice increases BDNF levels and prevents cognitive deficits as well as mitochondrial dysfunction. Cell Death Dis. 1:e91. doi: 10.1038/cddis.2010.73

Cortés, A., Gracia, E., Moreno, E., Mallol, J., Lluís, C., Canela, E. I., et al. (2015). Moonlighting adenosine deaminase: a target protein for drug development. Med. Res. Rev. 35, 85-125. doi: 10.1002/med.21324

Cortes-Canteli, M., Zamolodchikov, D., Ahn, H. J., Strickland, S., and Norris, E. H. (2012). Fibrinogen and altered hemostasis in Alzheimer's disease. J. Alzheimers Dis. 32, 599-608. doi: 10.3233/JAD-2012-120820

Cristalli, G., Costanzi, S., Lambertucci, C., Lupidi, G., Vittori, S., Volpini, R., et al. (2001). Adenosine deaminase: functional implications and different classes of inhibitors. Med. Res. Rev. 21, 105-128. doi: 10.1002/1098-1128(200103)21: $2<105:$ AID-MED1002>3.0.CO;2-U

Crouch, P. J., Wai, L., Adlard, P. A., Cortes, M., Lal, V., and Filiz, G. (2009). Increasing $\mathrm{Cu}$ bioavailability inhibits $\mathrm{A} \beta$ oligomers and tau phosphorylation. Proc. Natl. Acad. Sci. U.S.A. 106, 381-386. doi: 10.1073/pnas.08090 57106

Curtain, C. C., Ali, F., Volitakis, I., Cherny, R. A., Norton, R. S., Beyreuther, K., et al. (2001). Alzheimer's disease amyloid- $\beta$ binds copper and zinc to generate an allosterically ordered membrane-penetrating structure containing superoxide dismutase-like subunits. J. Biol. Chem. 276, 20466-20473. doi: 10.1074/jbc. M100175200

Da Settimo, F., Primofiore, G., La Motta, C., Taliani, S., Simorini, F., Marini, A. M., et al. (2005). Novel, highly potent adenosine deaminase inhibitors containing the pyrazolo[3,4-d]pyrimidine ring system. Synthesis, structureactivity relationships, and molecular modeling studies. J. Med. Chem. 48, 5162-5174. doi: 10.1021/jm050136d

Dai, X. L., Sun, Y. X., and Jiang, Z. F. (2006). Cu(II) potentiation of Alzheimer A $\beta 1$ 40 cytotoxicity and transition on its secondary structure. Acta Biochim. Biophys. Sin. 38, 765-772. doi: 10.1111/j.1745-7270.2006.00228.x

Dannenberger, D., Nuernberg, G., Renne, U., Nuernberg, K., Langhammer, M., Huber, K., et al. (2013). High-fat diets rich in u-3 or u-6 polyunsaturated fatty acids have distinct effects on lipid profiles and lipid peroxidation in mice selected for either high body weight or leanness. Nutrition 29, 765-771. doi: 10.1016/j.nut.2012.10.010

De Mendonça, A., and Ribeiro, J. A. (1996). Adenosine and neuronal plasticity. Life Sci. 60, 245-251. doi: 10.1016/S0024-3205(96)00544-9

Deibel, M. A., Ehmann, W. D., and Markesbery, W. R. (1996). Copper, iron, and zinc imbalances in severely degenerated brain regions in Alzheimer's disease: possible relation to oxidative stress. J. Neurol. Sci. 143, 137-142. doi: 10.1016/ S0022-510X(96)00203-1

Deloncle, R., and Guillard, O. (2014). Is brain copper deficiency in Alzheimer's, Lewy body, and Creutzfeldt Jakob diseases the common key for a free radical mechanism and oxidative stress-induced damage? J. Alzheimers Dis. 43, 1149-1156. doi: 10.3233/JAD-140765

Derakhshankhah, H., Hajipour, M. J., Barzegari, E., Lotfabadi, A., Ferdousi, M., Saboury, A. A., et al. (2016). Zeolite nanoparticles inhibit A $\beta$-fibrinogen interaction and formation of a consequent abnormal structural clot. ACS Appl. Mater. Interfaces 8, 30768-30779. doi: 10.1021/acsami.6b10941

Di Scala, C., Troadec, J. D., Lelièvre, C., Garmy, N., Fantini, J., and Chahinian, H. (2014). Mechanism of cholesterol-assisted oligomeric channel formation by a short Alzheimer $\beta$-amyloid peptide. J. Neurochem. 128, 186-195. doi: 10.1111/ jnc. 12390

Di Scala, C., Yahi, N., Boutemeur, S., Flores, A., Rodriguez, L., Chahinian, H., et al. (2016). Common molecular mechanism of amyloid pore formation by Alzheimer's $\beta$-amyloid peptide and $\alpha$-synuclein. Sci. Rep. 6:28781. doi: 10.1038/ srep28781

Dong, J., Atwood, C. S., Anderson, V. E., Siedlak, S. L., Smith, M. A., Perry, G., et al. (2003). Metal binding and oxidation of amyloid- $\beta$ within isolated senile plaque cores: Raman microscopic evidence. Biochemistry 42, 2768-2773. doi: 10.1021/bi0272151

Donnelly, P. S., Caragounis, A., Du, T., Laughton, K. M., Volitakis, I., Cherny, R. A., et al. (2008). Selective intracellular release of copper and zinc ions from bis(thiosemicarbazonato) complexes reduces levels of Alzheimer disease amyloid-beta peptide. J. Biol. Chem. 283, 4568-4577. doi: 10.1074/Jbc. M705957200

Drew, S. C. (2017). The case for abandoning therapeutic chelation of copper ions in Alzheimer's disease. Front. Neurosci. 11:317. doi: 10.3389/fnins.2017.00317

Drolle, E., Hane, F., Lee, B., and Leonenko, Z. (2014). Atomic force microscopy to study molecular mechanisms of amyloid fibril formation and toxicity in Alzheimer's disease. Drug Metab. Rev. 46, 207-223. doi: 10.3109/03602532.2014. 882354

Elder, G. A., Gama Sosa, M. A., and De Gasperi, R. (2010). Transgenic mouse models of Alzheimer's disease. Mt. Sinai J. Med. 77, 69-81. doi: 10.1002/msj. 20159

Eskici, G., and Axelsen, P. H. (2012). Copper and oxidative stress in the pathogenesis of Alzheimer's disease. Biochemistry 51, 6289-6311. doi: 10.1021/ bi3006169

Esparza, T. J., Zhao, H., Cirrito, J. R., Cairns, N. J., Bateman, R. J., Holtzman, D. M., et al. (2013). Amyloid-beta oligomerization in Alzheimer dementia versus high-pathology controls. Ann. Neurol. 73, 104-119. doi: 10.1002/ana.23748

Everett, J., Cespedes, E., Shelford, L. R., Exley, C., Collingwood, J. F., Dobson, J., et al. (2014). Ferrous iron formation following the co-aggregation of ferric iron and the Alzheimer's disease peptide beta-amyloid (1-42). J. R. Soc. Interface 11:20140165. doi: 10.1098/rsif.2014.0165

Exley, C. (2006). Aluminium and iron, but neither copper nor zinc, are key to the precipitation of beta-sheets of $A \beta_{42}$ in senile plaque cores in Alzheimer's disease. J. Alzheimers Dis. 10, 173-177. doi: 10.3233/JAD-2006-102-305

Exley, C., House, E., Polwart, A., and Esiri, M. M. (2012). Brain burdens of aluminum, iron, and copper and their relationships with amyloid- $\beta$ pathology in 60 human brains. J. Alzheimers Dis. 31, 725-730. doi: 10.3233/JAD-2012120766

Fang, C. L., Wu, W. H., Liu, Q., Sun, X., Ma, Y., Zhao, Y. F., et al. (2010). Dual functions of $\beta$-amyloid oligomer and fibril in $\mathrm{Cu}(\mathrm{II})$-induced $\mathrm{H}_{2} \mathrm{O}_{2}$ production. Regul. Pept. 163, 1-6. doi: 10.1016/j.regpep.2010.05.001

Feaga, H. A., Maduka, R. C., Foster, M. N., and Szalai, V. A. (2011). Affinity of $\mathrm{Cu}^{+}$ for the copper-binding domain of the amyloid- $\beta$ peptide of Alzheimer's disease. Inorg. Chem. 50, 1614-1618. doi: 10.1021/ic100967s

Flinn, J. M., Lorenzo Bozzelli, P., Adlard, P. A., and Railey, A. M. (2014). Spatial memory deficits in a mouse model of late-onset Alzheimer's disease are caused by zinc supplementation and correlate with amyloid-beta levels. Front. Aging Neurosci. 6:174. doi: 10.3389/fnagi.2014.00174

Fujiwara, N., Iso, H., Kitanaka, N., Kitanaka, J., Eguchi, H., Ookawara, T., et al. (2006). Effects of copper metabolism on neurological functions in Wistar and Wilson's disease model rats. Biochem. Biophys. Res. Commun. 349, 1079-1086. doi: $10.1016 /$ j.bbrc.2006.08.139

Gendron, T. F., and Petrucelli, L. (2009). The role of tau in neurodegeneration. Mol. Neurodegener. 4:13. doi: 10.1186/1750-1326-4-13

Geng, J., Li, M., Wu, L., Ren, J., and Qu, X. (2012). Liberation of copper from amyloid plaques: making a risk factor useful for Alzheimers disease treatment. J. Med. Chem. 55, 9146-9155. doi: 10.1021/jm3003813

Gerber, H., Wu, F., Dimitrov, M., Osuna, G. M. G., and Fraering, P. C. (2017). Zinc and copper differentially modulate amyloid precursor protein processing by $\gamma$-secretase and amyloid- $\beta$ peptide production. J. Biol. Chem. 292, 3751-3767. doi: 10.1074/jbc.M116.754101

Giacoppo, S., Galuppo, M., Calabrò, R. S., D’Aleo, G., Marra, A., Sessa, E., et al. (2014). Heavy metals and neurodegenerative diseases: an observational study. Biol. Trace Elem. Res. 161, 151-160. doi: 10.1007/s12011-0140094-5 
González, C., Martín, T., Cacho, J., Breñas, M. T., Arroyo, T., García-Berrocal, B., et al. (1999). Serum zinc, copper, insulin and lipids in Alzheimer's disease epsilon 4 apolipoprotein E allele carriers. Eur. J. Clin. Invest. 29, 637-642. doi: 10.1046/j.1365-2362.1999.00471.x

Grant, W. B. (1997). Dietary links to Alzheimer's disease. Alzheimers Dis. Rev. 2, 42-55.

Grasso, G., Pietropaolo, A., Spoto, G., Pappalardo, G., Tundo, G. R., Ciaccio, C., et al. (2011). Copper(I) and Copper(II) inhibit A $\beta$ peptides proteolysis by insulin-degrading enzyme differently: implications for metallostasis alteration in Alzheimer's disease. Chemistry 17, 2752-2762. doi: 10.1002/chem.20100 2809

Greenough, M. A., Camakaris, J., and Bush, A. I. (2013). Metal dyshomeostasis and oxidative stress in Alzheimer's disease. Neurochem. Int. 62, 540-555. doi: 10.1016/j.neuint.2012.08.014

Greenough, M. A., Ramírez Munoz, A., Bush, A. I., and Opazo, C. M. (2016). Metallo-pathways to Alzheimer's disease: lessons from genetic disorders of copper trafficking. Metallomics 8, 831-839. doi: 10.1039/c6mt00095a

Grundke-Iqbal, I., Fleming, J., Tung, Y. C., Lassmann, H., Iqbal, K., and Joshi, J. G. (1990). Ferritin is a component of the neuritic (senile) plaque in Alzheimer dementia. Acta Neuropathol. 81, 105-110. doi: 10.1007/BF00334497

Guan, C., Dang, R., Cui, Y., Liu, L., Chen, X., Wang, X., et al. (2017). Characterization of plasma metal profiles in Alzheimer's disease using multivariate statistical analysis. PLOS ONE 12:e0178271. doi: 10.1371/journal. pone.0178271s

Gunn, A. P., Wong, B. X., Johanssen, T., Griffith, J. C., Masters, C. L., Bush, A. I., et al. (2016). Amyloid-Beta peptide $A \beta 3 \mathrm{pE}-42$ induces lipid peroxidation, membrane permeabilization and calcium-influx in neurons. J. Biol. Chem. 42, 6134-6145. doi: 10.1074/jbc.M115.655183

Haeffner, F., Smith, D. G., Barnham, K. J., and Bush, A. I. (2005). Model studies of cholesterol and ascorbate oxidation by copper complexes: relevance to Alzheimer's disease $\beta$-amyloid metallochemistry. J. Inorg. Biochem. 99, 2403-2422. doi: 10.1016/j.jinorgbio.2005.09.011

Hane, F., Tran, G., Attwood, S. J., and Leonenko, Z. (2013). $\mathrm{Cu}^{2+}$ affects amyloid$\beta$ (1-42) aggregation by increasing peptide-peptide binding forces. PLOS ONE 8:e59005. doi: 10.1371/journal.pone.0059005

Hane, F. T., Hayes, R., Lee, B. Y., and Leonenko, Z. (2016). Effect of copper and zinc on the single molecule self-affinity of Alzheimer's amyloid-beta peptides. PLOS ONE 11:e0147488. doi: 10.1371/journal.pone.0147488

Harris, C. J., Voss, K., Murchison, C., Ralle, M., Frahler, K., Carter, R., et al. (2014). Oral zinc reduces amyloid burden in Tg2576 mice. J. Alzheimers Dis. 41, 179-192. doi: 10.3233/JAD- 131703

Hauber, W., and Bareiß, A. (2001). Facilitative effects of an adenosine A1/A2 receptor blockade on spatial memory performance of rats: selective enhancement of reference memory retention during the light period. Behav. Brain Res. 118, 43-52. doi: 10.1016/S0166-4328(00)00307-7

Hauser-Davis, R. A., de Freitas, L. V., Cukierman, D. S., Cruz, W. S., Miotto, M. C., Landeira-Fernandez, J., et al. (2015). Disruption of zinc and copper interactions with $\mathrm{A} \beta(1-40)$ by a non-toxic, isoniazid-derived, hydrazone: a novel biometal homeostasis restoring agent in Alzheimer's disease therapy? Metallomics 7, 743-747. doi: 10.1039/C5MT00003C

Holmes, C., Boche, D., Wilkinson, D., Yadegarfar, G., Hopkins, V., Bayer, A., et al. (2008). Long-term effects of A $\beta 42$ immunisation in Alzheimer's disease: followup of a randomised, placebo-controlled phase i trial. Lancet 372, 216-223. doi: 10.1016/S0140-6736(08)61075-2

Howlett, D. R., Richardson, J. C., Austin, A., Parsons, A. A., Bate, S. T., Davies, D. C., et al. (2004). Cognitive correlates of Abeta deposition in male and female mice bearing amyloid precursor protein and presenilin-1 mutant transgenes. Brain Res. 1017, 130-136. doi: 10.1016/j.brainres.2004.05.029

Hozumi, I., Hasegawa, T., Honda, A., Ozawa, K., Hayashi, Y., Hashimoto, K., et al. (2011). Patterns of levels of biological metals in CSF differ among neurodegenerative diseases. J. Neurol. Sci. 303, 95-99. doi: 10.1016/j.jns.2011. 01.003

Hu, D., Serrano, F., Oury, T. D., and Klann, E. (2006). Aging-dependent alterations in synaptic plasticity and memory in mice that overexpress extracellular superoxide dismutase. J. Neurosci. 26, 3933-3941. doi: 10.1523/JNEUROSCI. 5566-05.2006

Hua, H., Münter, L., Harmeier, A., Georgiev, O., Multhaup, G., and Schaffner, W. (2011). Toxicity of Alzheimer's disease-associated A $\beta$ peptide is ameliorated in a Drosophila model by tight control of zinc and copper availability. Biol. Chem. 392, 919-926. doi: 10.1515/BC.2011.084

Huang, X., Atwood, C. S., Moir, R. D., Hartshorn, M. A., Tanzi, R. E., and Bush, A. I. (2004). Trace metal contamination initiates the apparent auto-aggregation, amyloidosis, and oligomerization of Alzheimer's A $\beta$ peptides. J. Biol. Inorg. Chem. 9, 954-960. doi: 10.1007/s00775-004-0602-8

Huang, X., Cuajungco, M. P., Atwood, C. S., Hartshorn, M. A., Tyndall, J. D., Hanson, G. R., et al. (1999). Cu(II) potentiation of Alzheimer Aß neurotoxicity. J. Biol. Chem. 274, 37111-37116. doi: 10.1074/jbc.274.52.37111

Hung, V. W. S., Bressan, L. P., Seo, K., and Kerman, K. (2015). Electroanalysis of natural compounds as copper chelating agents for Alzheimer's disease therapy. Electroanalysis 27, 2670-2678. doi: 10.1002/elan.201500138

Hung, Y. H., Robb, E. L., Voltakis, I., Ho, M., Evin, G., Li, Q. X., et al. (2009). Paradoxical condensation of copper with elevated $\beta$-amyloid in lipid rafts under cellular copper deficiency conditions. Implications for Alzheimer disease. J. Biol. Chem. 284, 21899-21907. doi: 10.1074/jbc.M109.019521

Hureau, C. (2012). Coordination of redox active metal ions to the amyloid precursor protein and to amyloid beta peptides involved in Alzheimer disease. Part 1: an overview. Coord. Chem. Rev. 256, 2164-2174. doi: 10.1016/j.ccr.2012. 03.037

Jack, C. R., Knopman, D. S., Jagust, W. J., Shaw, L. M., Aisen, P. S., Weiner, M. W., et al. (2010). Hypothetical model of dynamic biomarkers of the Alzheimer's pathological cascade. Lancet Neurol. 9, 119-128. doi: 10.1016/S1474-4422(09) 70299-6

James, S. A., Churches, Q. I., De Jonge, M. D., Birchall, I. E., Streltsov, V., McColl, G., et al. (2017). Iron, copper, and zinc concentration in A $\beta$ plaques in the APP/PS1 mouse model of Alzheimer's disease correlates with metal levels in the surrounding neuropil. ACS Chem. Neurosci. 8, 629-637. doi: 10.1021/ acschemneuro.6b00362

James, S. A., Volitakis, I., Adlard, P. A., Duce, J. A., Masters, C. L., Cherny, R. A., et al. (2012). Elevated labile $\mathrm{Cu}$ is associated with oxidative pathology in Alzheimer disease. Free Radic. Biol. Med. 52, 298-302. doi: 10.1016/j. freeradbiomed.2011.10.446

Jiang, D., Li, X., Williams, R., Patel, S., Men, L., Wang, Y., et al. (2009). Ternary complexes of iron, amyloid- $\beta$, and nitrilotriacetic acid: binding affinities, redox properties, and relevance to iron-induced oxidative stress in Alzheimer's disease. Biochemistry 48, 7939-7947. doi: 10.1021/bi900907a

Jiao, Y., and Yang, P. (2007). Mechanism of copper(II) inhibiting Alzheimer's amyloid beta-peptide from aggregation: a molecular dynamics investigation. J. Phys. Chem. B 111, 7646-7655. doi: 10.1021/jp0673359

Jun, S., Gillespie, J. R., Shin, B. K., and Saxena, S. (2009). The second Cu(II)binding site in a proton-rich environment interferes with the aggregation of amyloid- $\beta(1-40)$ into amyloid fibrils. Biochemistry 48, 10724-10732. doi: 10.1021/bi9012935

Jung, C. K. E., Keppler, K., Steinbach, S., Blazquez-Llorca, L., and Herms, J. (2015). Fibrillar amyloid plaque formation precedes microglial activation. PLOS ONE 10:e0119768. doi: 10.1371/journal.pone.0119768

Kaden, D., Bush, A. I., Danzeisen, R., Bayer, T. A., and Multhaup, G. (2011). Disturbed copper bioavailability in Alzheimer's disease. Int. J. Alzheimers Dis. 2011:345614. doi: 10.4061/2011/345614

Kamsler, A., and Segal, M. (2003). Hydrogen peroxide modulation of synaptic plasticity. J. Neurosci. 23, 269-276.

Kamsler, A., and Segal, M. (2004). Hydrogen peroxide as a diffusible signal molecule in synaptic plasticity. Mol. Neurobiol. 29, 167-178. doi: 10.1385/MN: 29:2:167

Kepp, K. P. (2016). Alzheimer's disease due to loss of function: a new synthesis of the available data. Prog. Neurobiol. 143, 36-60. doi: 10.1016/j.pneurobio.2016. 06.004

Kessler, H., Bayer, T. A., Bach, D., Schneider-Axmann, T., Supprian, T., Herrmann, W., et al. (2008a). Intake of copper has no effect on cognition in patients with mild Alzheimer's disease: a pilot phase 2 clinical trial. J. Neural Transm. 115, 1181-1187. doi: 10.1007/s00702-008-0080-1

Kessler, H., Pajonk, F.-G., Bach, D., Schneider-Axmann, T., Falkai, P., Herrmann, W., et al. (2008b). Effect of copper intake on CSF parameters in patients with mild Alzheimer's disease: a pilot phase 2 clinical trial. J. Neural Transm. 115, 1181-1187. doi: 10.1007/s00702-008-0080-1

Kessler, H., Pajonk, F. G., Meisser, P., Schneider-Axmann, T., Hoffmann, K. H., Supprian, T., et al. (2006). Cerebrospinal fluid diagnostic markers correlate 
with lower plasma copper and ceruloplasmin in patients with Alzheimer's disease. J. Neural Transm. 113, 1763-1769. doi: 10.1007/s00702-0060485-7

Kessler, H., Pajonk, F. G., Supprian, T., Falkai, P., Multhaup, G., and Bayer, T. A. (2005). The role of copper in the pathophysiology of Alzheimer's disease. Nervenarzt 76, 581-585. doi: 10.1007/s00115-004-1849-6

Khan, A., Dobson, J. P., and Exley, C. (2006). Redox cycling of iron by Abeta42. Free Radic. Biol. Med. 40, 557-569. doi: 10.1016/j.freeradbiomed.2005. 09.013

Kishida, K. T., and Klann, E. (2007). Sources and targets of reactive oxygen species in synaptic plasticity and memory. Antioxid. Redox Signal. 9, 233-244. doi: 10.1089/ars.2007.9.ft-8

Klann, E. (1998). Cell-permeable scavengers of superoxide prevent longterm potentiation in hippocampal area CA1. J. Neurophysiol. 80, 452-457. doi: 10.1152/jn.1998.80.1.452

Klevay, L. M. (2008). Alzheimer's disease as copper deficiency. Med. Hypotheses 70, 802-807. doi: 10.1016/j.mehy.2007.04.051

Knapp, L. T., and Klann, E. (2002a). Role of reactive oxygen species in hippocampal long-term potentiation: contributory or inhibitory? J. Neurosci. Res. 70, 1-7.

Knapp, L. T., and Klann, E. (2002b). Potentiation of hippocampal synaptic transmission by superoxide requires the oxidative activation of protein kinase C. J. Neurosci. 22, 674-683.

Kong, G. K.-W., Miles, L. A., Crespi, G. A. N., Morton, C. J., Ng, H. L., Barnham, K. J., et al. (2008). Copper binding to the Alzheimer's disease amyloid precursor protein. Eur. Biophys. J. 37, 269-279. doi: 10.1007/s00249-007-0234-3

Kopf, S. R., Melani, A., Pedata, F., and Pepeu, G. (1999). Adenosine and memory storage: effect of $\mathrm{A}(1)$ and $\mathrm{A}(2)$ receptor antagonists. Psychopharmacology 146, 214-219. doi: 10.1007/s002130051109

Kotler, S. A., Walsh, P., Brender, J. R., and Ramamoorthy, A. (2014). Differences between amyloid- $\beta$ aggregation in solution and on the membrane: insights into elucidation of the mechanistic details of Alzheimer's disease. Chem. Soc. Rev. 43, 6692-6700. doi: 10.1039/C3CS60431D

Kozlowski, H., Luczkowski, M., Remelli, M., and Valensin, D. (2012). Copper, zinc and iron in neurodegenerative diseases (Alzheimer's, Parkinson's and prion diseases). Coord. Chem. Rev. 256, 2129-2141. doi: 10.1016/j.ccr.2012.03.013

La Motta, C., Sartini, S., Mugnaini, L., Salerno, S., Simorini, F., Taliani, S., et al. (2009). Exploiting the pyrazolo[3,4-d]pyrimidin-4-one ring system as a useful template to obtain potent adenosine deaminase inhibitors. J. Med. Chem. 52, 1681-1692. doi: 10.1021/jm801427r

Lang, M., Fan, Q., Wang, L., Zheng, Y., Xiao, G., Wang, X., et al. (2013). Inhibition of human high-affinity copper importer Ctrl orthologous in the nervous system of Drosophila ameliorates A $\beta$ 42-induced Alzheimer's disease-like symptoms. Neurobiol. Aging 34, 2604-2612. doi: 10.1016/j.neurobiolaging.2013.05.029

Larry, S. D. (2004). Cholesterol, copper, and accumulation of thioflavine S-reactive Alzheimer's-like amyloid beta in rabbit brain. J. Mol. Neurosci. 24, 97-104. doi: 10.1385/JMN:24:1:097

Lashuel, H. A., Hartley, D., Petre, B. M., Walz, T., and Lansbury, P. T. (2002). Neurodegenerative disease: amyloid pores from pathogenic mutations. Nature 418, 291-291. doi: 10.1038/418291a

Lee, H. G., Castellani, R. J., Zhu, X., Perry, G., and Smith, M. A. (2005). Amyloid- $\beta$ in Alzheimer's disease: the horse or the cart? Pathogenic or protective? Int. J. Exp. Pathol. 86, 133-138. doi: 10.1111/j.0959-9673.2005.00429.x

Leskovjan, A. C., Kretlow, A., Lanzirotti, A., Barrea, R., Vogt, S., and Miller, L. M. (2011). Increased brain iron coincides with early plaque formation in a mouse model of Alzheimer's disease. Neuroimage 55, 32-38. doi: 10.1016/j. neuroimage.2010.11.073

Leskovjan, A. C., Lanzirotti, A., and Miller, L. M. (2009). Amyloid plaques in PSAPP mice bind less metal than plaques in human Alzheimer's disease. Neuroimage 47, 1215-1220. doi: 10.1016/j.neuroimage.2009.05.063

Lesné, S., Koh, M. T., Kotilinek, L., Kayed, R., Glabe, C. G., Yang, A., et al. (2006). A specific amyloid- $\beta$ protein assembly in the brain impairs memory. Nature 440, 352-357. doi: 10.1038/nature04533

Li, D.-D., Zhang, W., Wang, Z.-Y., and Zhao, P. (2017). Serum copper, zinc, and iron levels in patients with Alzheimer's disease: a meta-analysis of case-control studies. Front. Aging Neurosci. 9:300. doi: 10.3389/fnagi.2017.00300

Linkous, D. H., Adlard, P. A., Wanschura, P. B., Conko, K. M., and Flinn, J. M. (2009). The effects of enhanced zinc on spatial memory and plaque formation in transgenic mice. J. Alzheimers Dis. 18, 565-579. doi: 10.3233/JAD-2009-1162
Liu, H. P., Lin, W. Y., Wang, W. F., Tsai, C. H., Wu, W. C., Chiou, M. T., et al. (2013). Genetic variability in copper-transporting P-type adenosine triphosphatase (ATP7B) is associated with Alzheimer's disease in a Chinese population. J. Biol. Regul. Homeost. Agents 27, 319-327.

Loef, M., von Stillfried, N., and Walach, H. (2012). Zinc diet and Alzheimer's disease: a systematic review. Nutr. Neurosci. 15, 2-12. doi: 10.1179/ 1476830512Y.0000000010

Lovell, M. A., Robertson, J. D., Teesdale, W. J., Campbell, J. L., and Markesbery, W. R. (1998). Copper, iron and zinc in Alzheimer's disease senile plaques. J. Neurol. Sci. 158, 47-52. doi: 10.1016/S0022-510X(98) 00092-6

Luo, Y. F., Zhang, J., Liu, N. Q., Luo, Y., and Zhao, B. L. (2011). Copper ions influence the toxicity of $\beta$-amyloid(1-42) in a concentration-dependent manner in a Caenorhabditis elegans model of Alzheimer's disease. Sci. China Life Sci. 54, 527-534. doi: 10.1007/s11427-011-4180-z

Lv, Z., Condron, M. M., Teplow, D. B., and Lyubchenko, Y. L. (2013). Nanoprobing of the effect of $\mathrm{Cu}^{2+}$ cations on misfolding, interaction and aggregation of amyloid $\beta$ peptide. J. Neuroimmune Pharmacol. 8, 262-273. doi: 10.1007/ s11481-012-9416-6

Ma, Q., Li, Y., Du, J., Liu, H., Kanazawa, K., Nemoto, T., et al. (2006). Copper binding properties of a tau peptide associated with Alzheimer's disease studied by CD, NMR, and MALDI-TOF MS. Peptides 27, 841-849. doi: 10.1016/j. peptides.2005.09.002

Macreadie, I. (2008). Copper transport and Alzheimer's disease. Eur. Biophys. J. 37, 295-300. doi: 10.1007/s00249-007-0235-2

Maiuolo, J., Oppedisano, F., Gratteri, S., Muscoli, C., and Mollace, V. (2016). Regulation of uric acid metabolism and excretion. Int. J. Cardiol. 213, 8-14. doi: 10.1016/j.ijcard.2015.08.109

Mao, X., Ye, J., Zhou, S., Pi, R., Dou, J., Zang, L., et al. (2012). The effects of chronic copper exposure on the amyloid protein metabolisim associated genes' expression in chronic cerebral hypoperfused rats. Neurosci. Lett. 518, 14-18. doi: 10.1016/j.neulet.2012.04.030

Marcellini, F., Giuli, C., Papa, R., Gagliardi, C., Dedoussis, G., Herbein, G., et al. (2006). Zinc status, psychological and nutritional assessment in old people recruited in five European countries: zincage study. Biogerontology 7, 339-345. doi: 10.1007/s10522-006-9048-4

Masters, C. L., and Selkoe, D. J. (2012). Biochemistry of amyloid $\beta$-protein and amyloid deposits in Alzheimer disease. Cold Spring Harb. Perspect. Med. 2:a006262. doi: 10.1101/cshperspect.a006262

Masters, C. L., Simms, G., Weinman, N. A., Multhaup, G., McDonald, B. L., and Beyreuther, K. (1985). Amyloid plaque core protein in Alzheimer disease and Down syndrome. Proc. Natl. Acad. Sci. U.S.A. 82, 4245-4249. doi: 10.1073/pnas. 82.12.4245

Mayes, J., Tinker-Mill, C., Kolosov, O., Zhang, H., Tabner, B. J., and Allsop, D. (2014). $\beta$-Amyloid fibrils in Alzheimer disease are not inert when bound to copper ions but can degrade hydrogen peroxide and generate reactive oxygen species. J. Biol. Chem. 289, 12052-12062. doi: 10.1074/jbc.M113.525212

Maylor, E. A., Simpson, E. E. A., Secker, D. L., Meunier, N., Andriollo-Sanchez, M., Polito, A., et al. (2006). Effects of zinc supplementation on cognitive function in healthy middle-aged and older adults: the ZENITH study. Br. J. Nutr. 96, 752-760. doi: 10.1079/bjn20061911

Maynard, C. J., Cappai, R., Volitakis, I., Cherny, R. A., Masters, C. L., Li, Q. X., et al. (2006). Gender and genetic background effects on brain metal levels in APP transgenic and normal mice: implications for Alzheimer beta-amyloid pathology. J. Inorg. Biochem. 100, 952-962. doi: 10.1016/j.jinorgbio.2006. 02.010

Maynard, C. J., Cappai, R., Volitakis, I., Cherny, R. A., White, A. R., Beyreuther, K., et al. (2002). Overexpression of Alzheimer's disease amyloid- $\beta$ opposes the agedependent elevations of brain copper and iron. J. Biol. Chem. 277, 44670-44676. doi: 10.1074/jbc.M204379200

Mercer, S. W., Wang, J., and Burke, R. (2017). In vivo modeling of the pathogenic effect of copper transporter mutations that cause Menkes and Wilson diseases, motor neuropathy, and susceptibility to Alzheimer's disease. J. Biol. Chem. 292, 4113-4122. doi: 10.1074/jbc.M116.756163

Miller, L. M., Wang, Q., Telivala, T. P., Smith, R. J., Lanzirotti, A., and Miklossy, J. (2006). Synchrotron-based infrared and X-ray imaging shows focalized accumulation of $\mathrm{Cu}$ and $\mathrm{Zn}$ co-localized with $\beta$-amyloid deposits in Alzheimer's disease. J. Struct. Biol. 155, 30-37. doi: 10.1016/j.jsb.2005.09.004 
Mital, M., Wezynfeld, N. E., Frączyk, T., Wiloch, M. Z., Wawrzyniak, U. E., Bonna, A., et al. (2015). A functional role for $A \beta$ in metal homeostasis? $\mathrm{N}$-truncation and high-affinity copper binding. Angew. Chem. Int. Ed. Engl. 54, 10460-10464. doi: 10.1002/anie.201502644

Moret, V., Laras, Y., Pietrancosta, N., Garino, C., Quéléver, G., Rolland, A., et al. (2006). 1,1'-Xylyl bis-1,4,8,11-tetraaza cyclotetradecane: a new potential copper chelator agent for neuroprotection in Alzheimer's disease. Its comparative effects with clioquinol on rat brain copper distribution. Bioorg. Med. Chem. Lett. 16, 3298-3301. doi: 10.1016/j.bmcl.2006.03.026

Morris, M. C., Evans, D. A., Tangney, C. C., Bienias, J. L., Schneider, J. A., Wilson, R. S., et al. (2006). Dietary copper and high saturated and trans fat intakes associated with cognitive decline. Arch. Neurol. 63, 1085-1088. doi: 10.1001/ archneur.63.8.1085

Multhaup, G., Schlicksupp, A., Hesse, L., Beher, D., Ruppert, T., Masters, C. L., et al. (1996). The amyloid precursor protein of Alzheimer's disease in the reduction of copper(II) to copper(I). Science 271, 1406-1409. doi: 10.1126/science.271.5254. 1406

Murray, I. V. J., Liu, L., Komatsu, H., Uryu, K., Xiao, G., Lawson, J. A., et al. (2007). Membrane-mediated amyloidogenesis and the promotion of oxidative lipid damage by amyloid $\beta$ proteins. J. Biol. Chem. 282, 9335-9345. doi: 10.1074/ jbc.M608589200

Nakamura, M., Shishido, N., Nunomura, A., Smith, M. A., Perry, G., Hayashi, Y., et al. (2007). Three histidine residues of amyloid-beta peptide control the redox activity of copper and iron. Biochemistry 46, 12737-12743. doi: 10.1021/ bi701079z

Nalivaeva, N. N., and Turner, A. J. (2013). The amyloid precursor protein: a biochemical enigma in brain development, function and disease. FEBS Lett. 587, 2046-2054. doi: 10.1016/j.febslet.2013.05.010

Naylor, R., Hill, A. F., and Barnham, K. J. (2008). Is covalently crosslinked Abeta responsible for synaptotoxicity in Alzheimer's disease? Curr. Alzheimer Res. 5, 533-539. doi: 10.2174/156720508786898433

Nguyen, M., Robert, A., Sournia-Saquet, A., Vendier, L., and Meunier, B. (2014) Characterization of new specific copper chelators as potential drugs for the treatment of Alzheimer's disease. Chemistry 20, 6771-6785. doi: 10.1002/chem. 201402143

Oddo, S., Caccamo, A., Shepherd, J. D., Murphy, M. P., Golde, T. E., Kayed, R., et al. (2003). Triple-transgenic model of Alzheimer's disease with plaques and tangles: intracellular A $\beta$ and synaptic dysfunction. Neuron 39, 409-421. doi: 10.1016/S0896-6273(03)00434-3

Ohno, M., and Watanabe, S. (1996). Working memory failure by stimulation of hippocampal adenosine A1 receptors in rats. Neuroreport 7, 3013-3016. doi: 10.1097/00001756-199611250-00043

Pajonk, F.-G., Kessler, H., Supprian, T., Hamzei, P., Bach, D., Schweickhardt, J., et al. (2005). Cognitive decline correlates with low plasma concentrations of copper in patients with mild to moderate Alzheimer's disease. J. Alzheimers Dis. 8, 23-27. doi: 10.3233/JAD-2005-8103

Pal, A., Badyal, R. K., Vasishta, R. K., Attri, S. V., Thapa, B. R., and Prasad, R. (2013). Biochemical, histological, and memory impairment effects of chronic copper toxicity: a model for non-Wilsonian brain copper toxicosis in Wistar rat. Biol. Trace Elem. Res. 153, 257-268. doi: 10.1007/s12011-013-9665-0

Pal, A., Kumar, A., and Prasad, R. (2014). Predictive association of copper metabolism proteins with Alzheimer's disease and Parkinson's disease: a preliminary perspective. Biometals 27, 25-31. doi: 10.1007/s10534-0139702-7

Parthasarathy, S., Yoo, B., McElheny, D., Tay, W., and Ishii, Y. (2014). Capturing a reactive state of amyloid aggregates: Nmr-based characterization of copperbound Alzheimer disease amyloid $\beta$-fibrils in a redox cycle. J. Biol. Chem. 289, 9998-10010. doi: 10.1074/jbc.M113.511345

Peng, F., Muzik, O., Gatson, J., Kernie, S. G., and Diaz-Arrastia, R. (2015) Assessment of traumatic brain injury by increased $64 \mathrm{Cu}$ uptake on 64CuCl2 PET/CT. J. Nucl. Med. 56, 1252-1257. doi: 10.2967/jnumed.115. 154575

Pereira, G. S., Mello e Souza, T., Vinadé, E. R. C., Choi, H., Rodrigues, C., Battastini, A. M. O., et al. (2002). Blockade of adenosine Al receptors in the posterior cingulate cortex facilitates memory in rats. Eur. J. Pharmacol. 437, 151-154. doi: 10.1016/S0014-2999(02)01307-9

Phinney, A. L., Drisaldi, B., Schmidt, S. D., Lugowski, S., Coronado, V., Liang, Y., et al. (2003). In vivo reduction of amyloid-beta by a mutant copper transporter.
Proc. Natl. Acad. Sci. U.S.A. 100, 14193-14198. doi: 10.1073/pnas.233285 1100

Pickart, L., Vasquez-Soltero, J. M., and Margolina, A. (2017). The effect of the human peptide GHK on gene expression relevant to nervous system function and cognitive decline. Brain Sci. 7:E20. doi: 10.3390/brainsci7020020

Pimentel, V. C., Gomes, J. L., Zanini, D., Abdalla, F. H., Da Costa, P., Gonçalves, J. F., et al. (2013). Evaluation of acetylcholinesterase and adenosine deaminase activities in brain and erythrocytes and proinflammatory cytokine levels in rats submitted to neonatal hypoxia-ischemia model. Mol. Cell. Biochem. 378, 247-255. doi: 10.1007/s11010-013-1615-9

Pithadia, A. S., and Lim, M. H. (2012). Metal-associated amyloid- $\beta$ species in Alzheimer's disease. Curr. Opin. Chem. Biol. 16, 67-73. doi: 10.1016/j.cbpa.2012. 01.016

Podlisny, M. B., Ostaszewski, B. L., Squazzo, S. L., Koo, E. H., Rydell, R. E., Teplow, D. B., et al. (1995). Aggregation of secreted amyloid beta-protein into sodium dodecyl sulfate-stable oligomers in cell culture. J. Biol. Chem. 270, 9564-9570. doi: $10.1074 /$ jbc. 270.16 .9564

Porkka-Heiskanen, T. (1999). Adenosine in sleep and wakefulness. Ann. Med. 31, 125-129. doi: 10.3109/07853899908998788

Pu, Z., Xu, W., Lin, Y., He, J., and Huang, M. (2017). Oxidative stress markers and metal ions are correlated with cognitive function in Alzheimer's disease. Am. J. Alzheimers Dis. Other Demen. 32, 353-359. doi: 10.1177/1533317517709549

Puglielli, L., Friedlich, A. L., Setchell, K. D. R., Nagano, S., Opazo, C., Cherny, R. A., et al. (2005). Alzheimer disease beta-amyloid activity mimics cholesterol oxidase. J. Clin. Invest. 115, 2556-2563. doi: 10.1172/JCI23610.2556

Quinn, J. F., Harris, C. J., Cobb, K. E., Domes, C., Ralle, M., Brewer, G., et al. (2010). A copper-lowering strategy attenuates amyloid pathology in a transgenic mouse model of Alzheimer's disease. J. Alzheimers Dis. 21, 903-914. doi: 10.3233/JAD2010-100408

Quintana, C., Bellefqih, S., Laval, J. Y., Guerquin-Kern, J. L., Wu, T. D., Avila, J., et al. (2006). Study of the localization of iron, ferritin, and hemosiderin in Alzheimer's disease hippocampus by analytical microscopy at the subcellular level. J. Struct. Biol. 153, 42-54. doi: 10.1016/j.jsb.2005.11.001

Rahman, A. (2009). The role of adenosine in Alzheimer's disease. Curr Neuropharmacol. 7, 207-216. doi: 10.2174/157015909789152119

Railey, A. M., Groeber, C. M., and Flinn, J. M. (2011). The effect of metals on spatial memory in a transgenic mouse model of Alzheimer's disease. J. Alzheimers Dis. 24, 375-381. doi: 10.3233/JAD-2011- 101452

Religa, D., Strozyk, D., Cherny, R. A., Volitakis, I., Haroutunian, V., Winblad, B., et al. (2006). Elevated cortical zinc in Alzheimer disease. Neurology 67, 69-75. doi: 10.1212/01.wnl.0000223644.08653.b5

Ribeiro, J. A., Sebastião, A. M., and De Mendonça, A. (2002). Adenosine receptors in the nervous system: pathophysiological implications. Prog. Neurobiol. 68, 377-392. doi: 10.1016/S0301-0082(02)00155-7

Riddell, D. R., Christie, G., Hussain, I., and Dingwall, C. (2001). Compartmentalization of $\beta$-secretase (Asp2) into low-buoyant density, noncaveolar lipid rafts. Curr. Biol. 11, 1288-1293. doi: 10.1016/S0960-9822(01) 00394-3

Ritchie, C. W., Bush, A. I., Mackinnon, A., Macfarlane, S., Mastwyk, M., MacGregor, L., et al. (2003). Metal-protein attenuation with iodochlorhydroxyquin (clioquinol) targeting Abeta amyloid deposition and toxicity in Alzheimer disease: a pilot phase 2 clinical trial. Arch. Neurol. 60, 1685-1691. doi: 10.1001/archneur.60.12.1685

Roberts, B. R., Ryan, T. M., Bush, A. I., Masters, C. L., and Duce, J. A. (2012) The role of metallobiology and amyloid- $\beta$ peptides in Alzheimer's disease. J. Neurochem. 120(Suppl. 1), 149-166. doi: 10.1111/j.1471-4159.2011.07500.x

Saboury, A. A., Bagheri, S., Ataie, G., Amanlou, M., Moosavi-Movahedi, A. A., Hakimelahi, G. H., et al. (2004). Binding properties of adenosine deaminase interacted with theophylline. Chem. Pharm. Bull. 52, 1179-1182. doi: 10.1248/ cpb.52.1179

Saboury, A. A., Bagheri, S., Ataie, G., Moosavi-Movahedi, A. A., Hakimelahi, G. H., Cristalli, G., et al. (2005). Kinetic and thermodynamic study on the inhibition of adenosine deaminase by theobromine. Asian J. Chem. 17, 233-239.

Saboury, A. A., Divsalar, A., Ataie, G., Amanlou, M., Moosavi-Movahedi, A. A., and Hakimelahi, G. H. (2003). Inhibition study of adenosine deaminase by caffeine using spectroscopy and isothermal titration calorimetry. Acta Biochim. Pol. 50, 849-855. 
Sandusky-Beltran, L. A., Manchester, B. L., and McNay, E. C. (2017). Supplementation with zinc in rats enhances memory and reverses an agedependent increase in plasma copper. Behav. Brain Res. 333, 179-183. doi: 10.1016/j.bbr.2017.07.007

Sarell, C. J. (2010). The Copper-Amyloid-beta-Peptide Complex of Alzheimer's Disease: Affinity, Structure, Fibril Formation and Toxicity. London: University of London.

Sarell, C. J., Syme, C. D., Rigby, S. E. J., and Viles, J. H. (2009). Copper(II) binding to amyloid- $\beta$ fibrils of Alzheimer's disease reveals a picomolar affinity: stoichiometry and coordination geometry are independent of $\mathrm{A} \beta$ oligomeric form. Biochemistry 48, 4388-4402. doi: 10.1021/bi900254n

Sarell, C. J., Wilkinson, S. R., and Viles, J. H. (2010). Substoichiometric levels of $\mathrm{Cu}^{2+}$ ions accelerate the kinetics of fiber formation and promote cell toxicity of amyloid- $\beta$ from Alzheimer disease. J. Biol. Chem. 285, 41533-41540. doi: 10.1074/jbc.M110.171355

Sasaguri, H., Nilsson, P., Hashimoto, S., Nagata, K., Saito, T., De Strooper, B., et al. (2017). APP mouse models for Alzheimer's disease preclinical studies. EMBO J. 36, 2473-2487. doi: 10.15252/embj.201797397

Savelieff, M. G., Liu, Y., Senthamarai, R. R. P., Korshavn, K. J., Lee, H. J., Ramamoorthy, A., et al. (2014). A small molecule that displays marked reactivity toward copper-versus zinc-amyloid- $\beta$ implicated in Alzheimer's disease. Chem. Commun. 50, 5301-5303. doi: 10.1039/c3cc48473d

Sayre, L. M., Perry, G., Harris, P. L. R., Liu, Y., Schubert, K. A., and Smith, M. A. (2000). In situ oxidative catalysis by neurofibrillary tangles and senile plaques in Alzheimer's disease. J. Neurochem. 74, 270-279. doi: 10.1046/j.1471-4159.2000. 0740270.x

Schrag, M., Mueller, C., Oyoyo, U., Smith, M. A., and Kirsch, W. M. (2011). Iron, zinc and copper in the Alzheimer's disease brain: a quantitative meta-analysis. Some insight on the influence of citation bias on scientific opinion. Prog. Neurobiol. 94, 296-306. doi: 10.1016/j.pneurobio.2011. 05.001

Schrag, M., Mueller, C., Zabel, M., Crofton, A., Kirsch, W. M., Ghribi, O., et al. (2013). Oxidative stress in blood in Alzheimer's disease and mild cognitive impairment: a meta-analysis. Neurobiol. Dis. 59, 100-110. doi: 10.1016/j.nbd. 2013.07.005

Selkoe, D. J. (2001). Alzheimer's disease: genes, proteins, and therapy. Physiol. Rev. 81, 741-766. doi: 10.1152/physrev.2001.81.2.741

Simpson, E. E. A., O’Connor, J. M., Livingstone, M. B. E., Rae, G., Stewart-Knox, B. J., Andriollo-Sanchez, M., et al. (2005). Health and lifestyle characteristics of older European adults: the ZENITH study. Eur. J. Clin. Nutr. 59, S13-S21. doi: 10.1038/sj.ejcn.1602292

Singh, I., Sagare, A. P., Coma, M., Perlmutter, D., Gelein, R., Bell, R. D., et al. (2013). Low levels of copper disrupt brain amyloid- $\beta$ homeostasis by altering its production and clearance. Proc. Natl. Acad. Sci. U.S.A. 110, 14771-14776. doi: 10.1073/pnas.1302212110

Smith, M. A., Harris, P. L., Sayre, L. M., and Perry, G. (1997). Iron accumulation in Alzheimer disease is a source of redox-generated free radicals. Proc. Natl. Acad. Sci. U.S.A. 94, 9866-9868. doi: 10.1073/pnas.94.18.9866

Southon, A., Greenough, M. A., Ganio, G., Bush, A. I., Burke, R., and Camakaris, J. (2013). Presenilin promotes dietary copper uptake. PLOS ONE 8:e62811. doi: 10.1371/journal.pone.0062811

Sparks, D. L. (2007). Cholesterol metabolism and brain amyloidosis: evidence for a role of copper in the clearance of Abeta through the liver. Curr. Alzheimer Res. 4, 165-169. doi: 10.2174/156720507780362119

Sparks, D. L., Friedland, R., Petanceska, S., Schreurs, B. G., Shi, J., Perry, G., et al. (2006). Trace copper levels in the drinking water, but not zinc or aluminum influence CNS Alzheimer-like pathology. J. Nutr. Health Aging 10, 247-254.

Sparks, D. L., and Schreurs, B. G. (2003). Trace amounts of copper in water induce beta-amyloid plaques and learning deficits in a rabbit model of Alzheimer's disease. Proc. Natl. Acad. Sci. U.S.A. 100, 11065-11069. doi: 10.1073/pnas. 1832769100

Sperling, R. A., Aisen, P. S., Beckett, L. A., Bennett, D. A., Craft, S., Fagan, A. M., et al. (2011). Toward defining the preclinical stages of Alzheimer's disease: recommendations from the National Institute on Aging-Alzheimer's Association workgroups on diagnostic guidelines for Alzheimer's disease. Alzheimers Dement. 7, 280-292. doi: 10.1016/j.jalz.2011.03.003

Squitti, R., Polimanti, R., Siotto, M., Bucossi, S., Ventriglia, M., Mariani, S., et al. (2013). ATP7B variants as modulators of copper dyshomeostasis in Alzheimer's disease. Neuromolecular Med. 15, 515-522. doi: 10.1007/s12017-0138237-y

Squitti, R., Salustri, C., Rongioletti, M., and Siotto, M. (2017a). Commentary: the case for abandoning therapeutic chelation of copper ions in Alzheimer's disease. Front. Neurol. 8:503. doi: 10.3389/fneur.2017.00503

Squitti, R., Simonelli, I., Ventriglia, M., Siotto, M., Pasqualetti, P., Rembach, A., et al. (2014a). Meta-analysis of serum non-ceruloplasmin copper in Alzheimer's disease. J. Alzheimers Dis. 38, 809-822. doi: 10.3233/JAD131247

Squitti, R., Siotto, M., and Polimanti, R. (2014b). Low-copper diet as a preventive strategy for Alzheimer's disease. Neurobiol. Aging 35(Suppl. 2), S40-S50. doi: 10.1016/j.neurobiolaging.2014.02.031

Squitti, R., Siotto, M., Arciello, M., and Rossi, L. (2016). Non-ceruloplasmin bound copper and ATP7B gene variants in Alzheimer's disease. Metallomics 8, 863-873. doi: 10.1039/C6MT00101G

Squitti, R., Ventriglia, M., Gennarelli, M., Colabufo, N. A., El Idrissi, I. G., Bucossi, S., et al. (2017b). Non-ceruloplasmin copper distincts subtypes in Alzheimer's disease: a genetic study of ATP7B frequency. Mol. Neurobiol. 54, 671-681. doi: 10.1007/s12035-015-9664-6

Streltsov, V. A., Titmuss, S. J., Epa, V. C., Barnham, K. J., Masters, C. L., and Varghese, J. N. (2008). The structure of the amyloid-beta peptide highaffinity copper II binding site in Alzheimer disease. Biophys. J. 95, 3447-3456. doi: 10.1529/biophysj.108.134429

Strozyk, D., Launer, L., and Adlard, P. (2009). Zinc and copper modulate Alzheimer A $\beta$ levels in human cerebrospinal fluid. Neurobiol. Aging 30, 1069-1077. doi: 10.1016/j.neurobiolaging.2007.10.012.Zinc

Suh, S. W., Jensen, K. B., Jensen, M. S., Silva, D. S., Kesslak, P. J., Danscher, G., et al. (2000). Histochemically-reactive zinc in amyloid plaques, angiopathy, and degenerating neurons of Alzheimer's diseased brains. Brain Res. 852, 274-278. doi: 10.1016/S0006-8993(99)02096-X

Suzuki, K., Miura, T., and Takeuchi, H. (2001). Inhibitory effect of copper(II) on zinc(II)-induced aggregation of amyloid $\beta$-peptide. Biochem. Biophys. Res. Commun. 285, 991-996. doi: 10.1006/bbrc.2001.5263

Swerdlow, R. H. (2011). Brain aging, Alzheimer's disease, and mitochondria. Biochim. Biophys. Acta 1812, 1630-1639. doi: 10.1016/j.bbadis.2011. 08.012

Szabo, S. T., Jean Harry, G., Hayden, K. M., Szabo, D. T., and Birnbaum, L. (2016). Comparison of metal levels between postmortem brain and ventricular fluid in Alzheimer's disease and nondemented elderly controls. Toxicol. Sci. 150, 292-300. doi: 10.1093/toxsci/kfv325

Tabner, B. J., Mayes, J., and Allsop, D. (2011). Hypothesis: soluble A $\beta$ oligomers in association with redox-active metal ions are the optimal generators of reactive oxygen species in Alzheimer's disease. Int. J. Alzheimers Dis. 2011:546380. doi: $10.4061 / 2011 / 546380$

Talwar, P., Grover, S., Sinha, J., Chandna, P., Agarwal, R., Kushwaha, S., et al. (2017). Multifactorial analysis of a biomarker pool for Alzheimer disease risk in a North Indian population. Dement. Geriatr. Cogn. Disord. 44, 25-34. doi: 10.1159/000477206

Tao, Y., Wang, Y., Rogers, J. T., and Wang, F. (2014). Perturbed iron distribution in Alzheimer's disease serum, cerebrospinal fluid, and selected brain regions: a systematic review and meta-analysis. J. Alzheimers Dis. 42, 679-690. doi: 10.3233/JAD- 140396

Tecchio, F., Vecchio, F., Ventriglia, M., Porcaro, C., Miraglia, F., Siotto, M., et al. (2016). Non-ceruloplasmin copper appears a distinct subtype of Alzheimer's disease: a study of EEG-derived brain activity. Curr. Alzheimer Res. 13, 1374-1384. doi: 10.2174/1567205013666160603001131

Terasaka, T., Kinoshita, T., Kuno, M., and Nakanishi, I. (2004a). A highly potent non-nucleoside adenosine deaminase inhibitor: efficient drug discovery by intentional lead hybridization. J. Am. Chem. Soc. 126, 34-35. doi: 10.1021/ ja0386061

Terasaka, T., Kinoshita, T., Kuno, M., Seki, N., Tanaka, K., and Nakanishi, I. (2004b). Structure-based design, synthesis, and structure-activity relationship studies of novel non-nucleoside adenosine deaminase inhibitors. J. Med. Chem. 47, 3730-3743.

Torres, J. B., Andreozzi, E. M., Dunn, J. T., Siddique, M., Szanda, I., Howlett, D. R., et al. (2016). PET imaging of copper trafficking in a mouse model of Alzheimer disease. J. Nucl. Med. 57, 109-114. doi: 10.2967/jnumed.115. 162370 
Tõugu, V., Karafin, A., and Palumaa, P. (2008). Binding of zinc(II) and copper(II) to the full-length Alzheimer's amyloid- $\beta$ peptide. J. Neurochem. 104, 1249-1259. doi: 10.1111/j.1471-4159.2007.05061.x

Tõugu, V., Karafin, A., Zovo, K., Chung, R. S., Howells, C., West, A. K., et al. (2009). $\mathrm{Zn}(\mathrm{II})$ - and $\mathrm{Cu}(\mathrm{II})$-induced non-fibrillar aggregates of amyloid- $\beta$ (1-42) peptide are transformed to amyloid fibrils, both spontaneously and under the influence of metal chelators. J. Neurochem. 110, 1784-1795. doi: 10.1111/j.14714159.2009.06269.x

Ujjinamatada, R. K., Phatak, P., Burger, A. M., and Hosmane, R. S. (2008). Inhibition of adenosine deaminase by analogues of adenosine and inosine, incorporating a common heterocyclic base, 4(7)-amino-6(5)H-imidazo[4,5-d] pyridazin-7(4)one. J. Med. Chem. 51, 694-698. doi: 10.1021/jm700931t

Unzeta, M., Esteban, G., Bolea, I., Fogel, W. A., Ramsay, R. R., Youdim, M. B. H., et al. (2016). Multi-target directed donepezil-like ligands for Alzheimer's disease. Front. Neurosci. 10:205. doi: 10.3389/fnins.2016.00205

Ventriglia, M., Brewer, G. J., Simonelli, I., Mariani, S., Siotto, M., Bucossi, S., et al. (2015). Zinc in Alzheimer's disease: a meta-analysis of serum, plasma, and cerebrospinal fluid studies. J. Alzheimers Dis. 46, 75-87. doi: 10.3233/JAD141296

Ventriglia, M., Bucossi, S., Panetta, V., and Squitti, R. (2012). Copper in Alzheimer's disease: a meta-analysis of serum, plasma, and cerebrospinal fluid studies. J. Alzheimers Dis. 30, 981-984. doi: 10.3233/JAD-2012-120244

Vigo-Pelfrey, C., Lee, D., Keim, P., Lieberburg, I., and Schenk, D. B. (1993). Characterization of beta-amyloid peptide from human cerebrospinal fluid. J. Neurochem. 61, 1965-1968. doi: 10.1111/j.1471-4159.1993.tb09841.x

Viles, J. H. (2012). Metal ions and amyloid fiber formation in neurodegenerative diseases. Copper, zinc and iron in Alzheimer's, Parkinson's and prion diseases. Coord. Chem. Rev. 256, 2271-2284. doi: 10.1016/j.ccr.2012.05.003

Vural, H., Demirin, H., Kara, Y., Eren, I., and Delibas, N. (2010). Alterations of plasma magnesium, copper, zinc, iron and selenium concentrations and some related erythrocyte antioxidant enzyme activities in patients with Alzheimer's disease. J. Trace Elem. Med. Biol. 24, 169-173. doi: 10.1016/j.jtemb.2010.02.002

Waggoner, D. J., Bartnikas, T. B., and Gitlin, J. D. (1999). The role of copper in neurodegenerative disease. Neurobiol. Dis. 6, 221-230. doi: 10.1006/nbdi.1999. 0250

Walsh, D. M., Klyubin, I., Fadeeva, J. V., Cullen, W. K., Anwyl, R., Wolfe, M. S., et al. (2002). Naturally secreted oligomers of amyloid $\beta$ protein potently inhibit hippocampal long-term potentiation in vivo. Nature 416, 535-539. doi: 10.1038/ $416535 \mathrm{a}$

Wan, L., Nie, G., Zhang, J., Luo, Y., Zhang, P., Zhang, Z., et al. (2011). $\beta$-Amyloid peptide increases levels of iron content and oxidative stress in human cell and Caenorhabditis elegans models of Alzheimer disease. Free Radic. Biol. Med. 50, 122-129. doi: 10.1016/j.freeradbiomed.2010.10.707

Wang, Z.-X., Tan, L., Wang, H.-F., Ma, J., Liu, J., Tan, M.-S., et al. (2015). Serum iron, zinc, and copper levels in patients with Alzheimer's disease: a replication study and meta-analyses. J. Alzheimers Dis. 47, 565-581. doi: 10.3233/JAD143108

Weingarten, M. D., Lockwood, A. H., Hwo, S. Y., and Kirschner, M. W. (1975). A protein factor essential for microtubule assembly. Proc. Natl. Acad. Sci. U.S.A. 72, 1858-1862. doi: 10.1073/pnas.72.5.1858
Wild, K., August, A., Pietrzik, C. U., and Kins, S. (2017). Structure and synaptic function of metal binding to the amyloid precursor protein and its proteolytic fragments. Front. Mol. Neurosci. 10:21. doi: 10.3389/fnmol.2017.00021

Wong, B. X., Hung, Y. H., Bush, A. I., and Duce, J. A. (2014). Metals and cholesterol: two sides of the same coin in Alzheimer's disease pathology. Front. Aging Neurosci. 6:91. doi: 10.3389/fnagi.2014.00091

Wright, A. L., Zinn, R., Hohensinn, B., Konen, L. M., Beynon, S. B., Tan, R. P., et al. (2013). Neuroinflammation and neuronal loss precede $A \beta$ plaque deposition in the hAPP-J20 mouse model of Alzheimer's disease. PLOS ONE 8:e59586. doi: 10.1371/journal.pone.0059586

Wu, W. H., Lei, P., Liu, Q., Hu, J., Gunn, A. P., Chen, M. S., et al. (2008). Sequestration of copper from $\beta$-amyloid promotes selective lysis by cyclenhybrid cleavage agents. J. Biol. Chem. 283, 31657-31664. doi: 10.1074/jbc. M804722200

Xie, H., Hou, S., Jiang, J., Sekutowicz, M., Kelly, J., and Bacskai, B. J. (2013). Rapid cell death is preceded by amyloid plaque-mediated oxidative stress. Proc. Natl. Acad. Sci. U.S.A. 110, 7904-7909. doi: 10.1073/pnas.1217938110

Yang, T., Yang, L., Zhang, C., Wang, Y., Ma, X., Wang, K., et al. (2016). A copper-amyloid- $\beta$ targeted fluorescent chelator as a potential theranostic agent for Alzheimer's disease. Inorg. Chem. Front. 3, 1572-1581. doi: 10.1039/ C6QI00268D

Yao, F., Zhang, R., Tian, H., and Li, X. (2012). Studies on the interactions of copper and zinc ions with $\beta$-amyloid peptides by a surface plasmon resonance biosensor. Int. J. Mol. Sci. 13, 11832-11843. doi: 10.3390/ijms1309 11832

Yermolaieva, O., Brot, N., Weissbach, H., Heinemann, S. H., and Hoshi, T. (2000). Reactive oxygen species and nitric oxide mediate plasticity of neuronal calcium signaling. Proc. Natl. Acad. Sci. U.S.A. 97, 448-453. doi: 10.1073/pnas.97. 1.448

Yu, J., Luo, X., Xu, H., Ma, Q., Yuan, J., Li, X., et al. (2015). Identification of the key molecules involved in chronic copper exposure-aggravated memory impairment in transgenic mice of Alzheimer's disease using proteomic analysis. J. Alzheimers Dis. 44, 455-469. doi: 10.3233/JAD-141776

$\mathrm{Yu}, \mathrm{X}$., and Zheng, J. (2012). Cholesterol promotes the interaction of Alzheimer $\beta$-amyloid monomer with lipid bilayer. J. Mol. Biol. 421, 561-571. doi: 10.1016/ j.jmb.2011.11.006

Zhang, Y., Thompson, R., Zhang, H., and Xu, H. (2011). APP processing in Alzheimer's disease. Mol. Brain 4:3. doi: 10.1186/1756-6606-4-3

Conflict of Interest Statement: The authors declare that the research was conducted in the absence of any commercial or financial relationships that could be construed as a potential conflict of interest.

Copyright (c) 2018 Bagheri, Squitti, Haertlé, Siotto and Saboury. This is an openaccess article distributed under the terms of the Creative Commons Attribution License (CC BY). The use, distribution or reproduction in other forums is permitted, provided the original author(s) or licensor are credited and that the original publication in this journal is cited, in accordance with accepted academic practice. No use, distribution or reproduction is permitted which does not comply with these terms. 